\title{
Beloceras, the most multilobate Late Devonian ammonoid
}

\author{
DIETER KORN, JÜRGEN BOCKWINKEL, VOLKER EBbIGHAUSEN \& SONNY A. WALTON
}

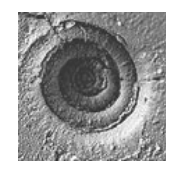

\begin{abstract}
Beloceras is the most multilobate among the Late Devonian ammonoids, with a suture line composing up to 50 or more singular lobes. Revision of the material from the Rhenish Mountains and Thuringian Mountains of Germany and the Anti-Atlas of Morocco led to the conclusion that endemic species can be identified mainly on the base of differences in the suture line. The species Beloceras sagittarium (Sandberger \& Sandberger, 1851), Beloceras tenuistriatum (d'Archiac \& de Verneuil, 1842), and Beloceras webbelense sp. nov. are described from the Rhenish Mountains and Beloceras petterae Yatskov, 1990 as well as Beloceras jorfense sp. nov. from the Anti-Atlas. - Key words: Ammonoidea, Gephuroceratina, Beloceratidae, Frasnian, morphometrics, suture line.
\end{abstract}

Korn, D., BocKWInKel, J., EBbighausen, V. \& WALton, S.A. 2011. Beloceras, the most multilobate Late Devonian ammonoid. Bulletin of Geosciences 86(1), 1-28 (18 figures, 11 tables, appendix). Czech Geological Survey, Prague. ISSN 1214-1119. Manuscript received November 16, 2010; accepted in revised form January 11, 2011; published online February 15, 2011; issued March 14, 2011.

Dieter Korn (corresponding author), Museum für Naturkunde Berlin, Invalidenstraße 43, D-10115 Berlin, Germany; dieter.korn@mfn-berlin.de • Jürgen Bockwinkel, Dechant-Feinstraße 22, D-51375 Leverkusen, Germany; jbockwinkel@t-online.de•Volker Ebbighausen, Engstenberger Höhe 12, D-51519Odenthal, Germany; volker@vxr.de - Sonny A. Walton, Museum für Naturkunde Berlin, Invalidenstraße 43, D-10115 Berlin, Germany; sonnywalton30@hotmail.com

The Frasnian ammonoid assemblages are characterised by a wide spectrum of morphologies, in which species with simple conch morphology (i.e. with similar conch geometry throughout ontogeny) and also a simple suture line (i.e. with few sutural elements) co-occurred with species possessing highly complex multilobate suture lines and a rather complex conch ontogeny (e.g. Korn \& Klug 2002). The ammonoid family with the highest number of sutural elements in the Frasnian is the Beloceratidae, with some species possessing conchs with up to 50 or even more lobes Beloceras specimens may be quite large, with conch diameters reaching up to $300 \mathrm{~mm}$ (B. sagittarium). The most advanced Late Devonian ammonoids belong to this genus, having the most complex suture line and an extremely discoidal conch, occupying a marginal position in the morphospace occupied by the Devonian ammonoids.

Beloceras or closely related genera have been reported from practically all regions in which Frasnian ammonoids have been found. An exception to this distribution is the Timan, but from this region young specimens of Beloceras were misinterpreted and described as Nordiceras (Bogoslovsky 1958, 1969).

Beloceras is a genus that urgently requires a revision based on the original material. Up to now, only a few of the occurrences have been described with sufficient material, but even for the type species a clear demarcation has not been drawn. For instance, it was not clear if all the specimens from the Rhenish Mountains belong to only one species, or if B. tenuistriatum has a global distribution, occurring in the Rhenish Mountains, the Anti-Atlas, the Canning Basin, etc. Yatskov (1990) has proposed a number of new species (see below) with the hypothesis that each regional occurrence has its own endemic species. The evidence for such a view was weak, and hence these names usually have been treated as synonyms. Although such endemism cannot be excluded, a thorough revision is necessary to support this hypothesis.

In this report, specimens from the Rhenish Mountains and the Anti-Atlas are revised based on previously unpublished material in order to outline the morphological spectrum of the Beloceratidae in the two regions.

\section{Geographic and stratigraphic distribution of Beloceras}

Specimens of Beloceras and closely related genera are known from a number of regions, reviewed below (Fig. 1).

Rhenish Mountains: Beyrich (1837) described a species under the name 'Ammonites multilobatus' from the 
"rothen Goniatiten-Kalk von Oberscheld", but unfortunately it is not known where the type material has been stored. From the description and illustration of the suture line it is most likely a species of Beloceras. Anyway 'Ammonites multilobatus Beyrich, 1837' is a junior homonym of 'Ammonites multilobatus Bronn, 1832' and hence invalid.

D'Archiac \& de Verneuil (1842) described 'Goniatites tenuistriatus' from Oberscheld and their very accurate lithographic illustrations allow a rather clear characterisation of the conch geometry. Unfortunately, d'Archiac \& de Verneuil (1842) did not illustrate suture lines of their species and the current whereabouts of this material is not known. Sandberger \& Sandberger (1851) described 'Goniatites Sagittarius' from Seßacker near Oberscheld, mainly based on a large septate specimen.

Occurrences of the genus Beloceras in the Rhenish Mountains (Fig. 2) were subsequently reported several times. Holzapfel (1882) listed 'Beloceras multilobatum Beyrich, 1837' from the Martenberg and Webbel Mine near Adorf and the Charlottenzug Mine near Bredelar. This means that he did not separate between the three species described in this article; according to his illustrations we can infer that the most likely identity for his specimens is $B$. webbelense sp. nov. He also newly introduced 'Beloceras Kayseri', which is now attributed to the genus Mesobeloceras.

Wedekind $(1913,1918)$ listed 'Beloceras multilobatum Beyrich, 1837', 'Beloceras Kayseri Holzapfel, 1882', and the new species 'Beloceras Denckmanni' from the Martenberg near Adorf. The latter two are now attributed to Mesobeloceras. Matern (1931) gave faunal lists including 'Beloceras multilobatum Beyrich, 1837' and 'Beloceras Kayseri Holzapfel, 1882' from localities in the area of Oberscheld, but he did not describe or figure the material. Clausen (in Clausen et al. 1991) figured 'Beloceras cf. sagittarium $\rightarrow$ Beloceras subacutum' from the Beringhausen Tunnel, including the first cross section of the genus from the Rhenish Mountains.

For a long time it was not clear which species names were valid for the material; most of the authors used the names ' $B$. multilobatum' and ' $B$. sagittarium'. Schindewolf (1940) then claimed that ' $B$. tenuistriatum d'Archiac $\&$ de Verneuil (1842)' is the species name having priority over $B$. sagittarium, however, the two species are separated here.

Thuringian Mountains: Müller (1956) described 'Beloceras multilobatum Beyrich, 1837' from the upper Manticoceras Stufe of the Geipel quarry near Schleiz.

Devonshire: Foord \& Crick (1897) and House (1963) listed 'Beloceras sagittarium' from the area of Chudley.

Cantabrian Mountains: Poorly preserved material of 'Beloceras cf. tenuistriatum' was reported by Kullmann (1960) from the Arruz region of Palencia. From the León province, Kullmann (1963) figured 'Beloceras tenuistriatum'.

Menorca: Hermite (1887) listed material from Santa Rita under the name 'Beloceras multilobatum'. This material has not been revised.

Pyrenees: The occurrence of Beloceras was reported from the Pyrenees (e.g. Sanz-López 2002), but the specimens have not been described.

Montagne Noire: A well-preserved specimen from the 'Pic de Cabrières' of 'Beloceras multilobatum Beyrich, 1837' has been figured by Frech (1897, pl. 32a, fig. 9). Frech (1897, p. 177f, text-fig. 1 and 1902, p. 60, text-fig. 19) figured the suture line of the specimen two times (once rotated by 180 degrees). The illustrated specimen is involute ( $\mathrm{uw} / \mathrm{dm}=0.09$ ) and in this respect closely resembles Beloceras sagittarium (Sandberger \& Sandberger, 1851) and Beloceras stenumbilicatum Bogoslovsky, 1958. The suture line figured by Frech (1897, $1902)$ is obviously not correct, as Frech (1902, p. 60) stated himself. The figures show more or less triangular lobes and saddles, but the photograph (Frech 1897, pl. 32a, fig. 9) shows lanceolate secondary prongs of the external lobe.

Böhm (1935) described additional fragmentary specimens of 'Beloceras multilobatum Beyrich, 1837' from Coumiac. Schulz (1967) described more and better-preserved material from this locality under the species name 'Beloceras sagittarium (Sandberger \& Sandberger, 1851)'. Schulz showed suture lines, which occasionally display serrated lobes (lateral lobe and outer umbilical lobe). On the basis of this observation House \& Kirchgasser (in House et al. 1985) identified two species within the assemblage, attributed to different genera, namely 'Beloceras sagittarium (Sandberger \& Sandberger, 1851)' for the specimens lacking serration and 'Ceratobeloceras schulzi House \& Kirchgasser (1985)' for the specimens with 'ceratitic subdivision of the ventrad umbilical lobes'. Yatskov (1990) then renamed the specimens with non-serrated lobes and introduced the new species 'Beloceras (Beloceras) gallicum Yatskov, 1990' and chose a holotype from the material described by Schulz (1967). Becker \& House (1994) did not use this name and figured non-serrated specimens under the species name 'Beloceras tenuistriatum (d'Archiac \& de Verneuil, 1842)'. Further studies are required to show if the material from the Montagne Noire represents synonyms of other species or if they are endemic species.

Carnic Alps: Frech (1902, pl. 4, fig. 11) figured a fragment of a rather large specimen from the Valentintörl; according to his misinterpretation of the age of the specimen (Frech thought that it came from Early Devonian rocks), he introduced the new species 'Beloceras praecursor Frech, 1902'. The fragment has a whorl height of about $50 \mathrm{~mm}$ and is multilobate with at least six secondary prongs on the external lobe. According to the figure, which shows rather 

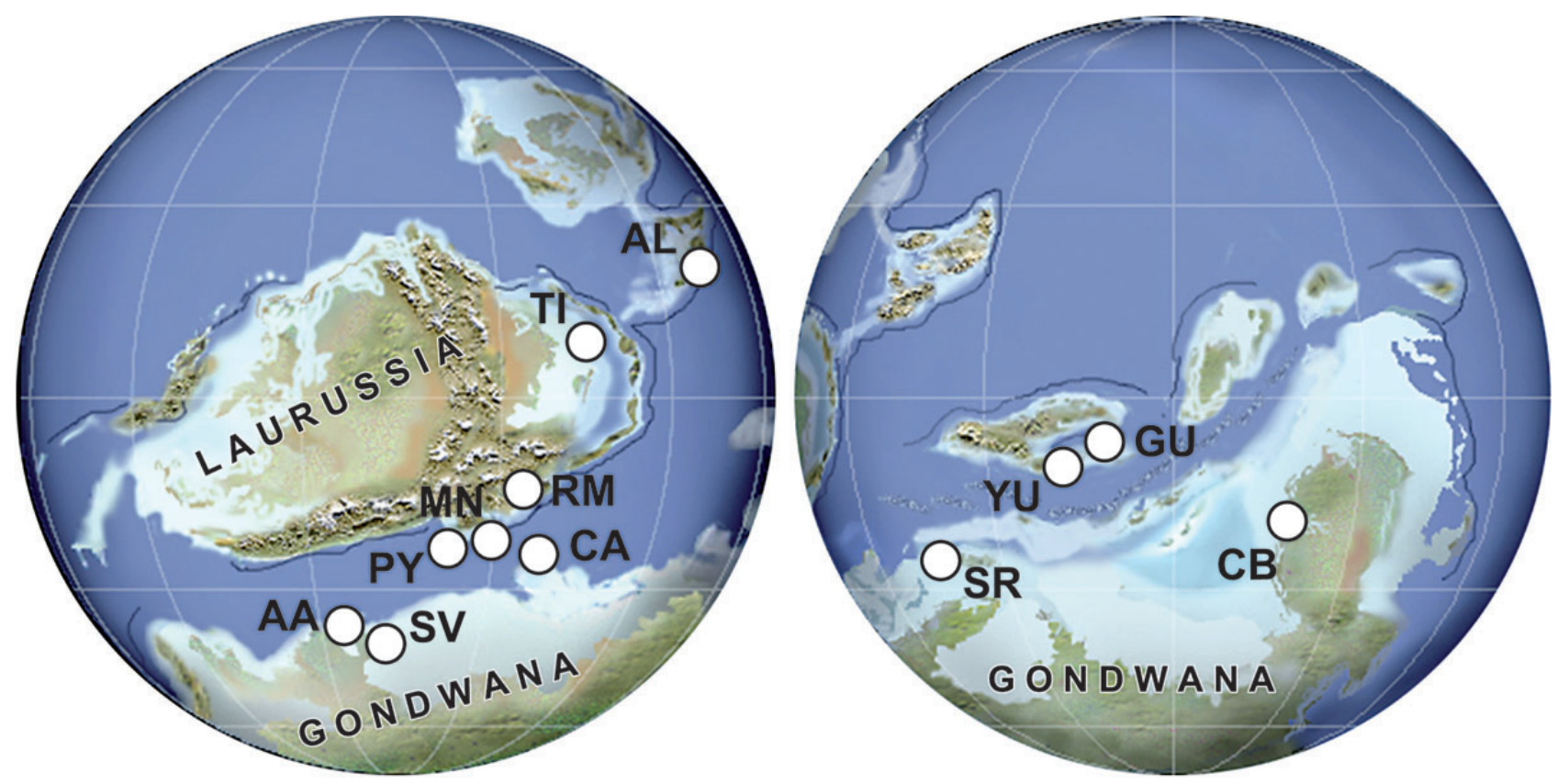

Figure 1. Palaeogeographic reconstruction of the Late Devonian (after Ron Blakey, http://jan.ucc.nau.edu/ rcb7/index.html) with the proposed positions of the occurrences of the genus Beloceras. Abbreviations: AA - Anti-Atlas, SV - Saoura Valley, PY - Pyrenees, MN - Montagne Noire, CA Carnic Alps; RM - Rhenish Mountains, TI - Timan, AL - Altay, SR - Shotori Range, YU - Yunnan, GU - Guangxi, CB - Canning Basin.

symmetric V-shaped lobes and also triangular saddles, it can be assumed that the specimen was polished and that details of the suture line were erased.

Timan: The genus Beloceras was believed to be absent in the ammonoid-rich occurrences of the Timan. However, 'Prolecanites timanicus Holzapfel, 1899', was based on small specimens with a maximum diameter of $20 \mathrm{~mm}$. Bogoslovsky $(1955,1969)$ introduced the new genus name Nordiceras for this problematic species and placed it in the family Pharciceratidae. Becker \& House (in Becker et al. 2000) revised some of the species, which are important for the Frasnian succession of the Timan, including Nordiceras timanicum. They illustrated newly collected material from this species, but this was also rather small (less than $13 \mathrm{~mm}$ in $\mathrm{dm}$ ). The authors introduced the Nordiceras timanicum Zone for an interval in the middle Frasnian Domanik Formation and correlated this zone tentatively with the Beloceras tenuistriatum Zone. Korn \& Klug (2002) introduced the new family Nordiceratidae for the genus Nordiceras and placed it in the Belocerataceae.

The Beloceras material from Büdesheim has a particularly close morphological resemblance with Nordiceras timanicum in all respects. The minor differences regard the ornament (with weak folds on the outer flank in B. sagittarium), and the suture line that shows a slightly faster ontogenetic development in the latter species. The consequence of this is that the genus Nordiceras has to be put into synonymy with Beloceras and the family Nordiceratidae into synonymy with the family Beloceratidae.
Altay: Bogoslovsky $(1958,1969)$ described two species, one of which he attributed to 'Beloceras sagittarium (Sandberger \& Sandberger, 1851)' and the other, Beloceras stenumbilicatum Bogoslovsky, 1958, was new. Bogoslovsky noticed narrowly and widely umbilicate conch forms within ' $B$. sagittarium' and this material was later (Yatskov 1990) used for the description of a new species 'Mesobeloceras bogoslovskyi Yatskov, 1990'.

Saoura Valley: Termier \& Termier (1950, text-figs 25-27) figured a specimen of 'Beloceras sagittarium (Sandberger \& Sandberger, 1851)’ from Béni Abbès in Algeria. The (possibly inaccurate) suture line figure shows an external lobe with just two secondary prongs, a lateral lobe and four umbilical lobes on the flank. Such a configuration is unlikely, but Yatskov (1990) used this figure for his new species 'Sinobeloceras termieri Yatskov, 1990' to represent an evolutionary lineage in which the subdivision of the external lobe is decelerated.

Petter (1959) described the new species 'Beloceras subacutum' based on a whorl fragment from Béni-Abbès. According to her figures (Petter 1959, pl. 10, fig. 4, text-fig. 44C), this specimen must belong to Mesobeloceras. However, Yatskov (1990) used this species as the type species of his new genus Atopobeloceras.

Anti-Atlas: Petter (1959) figured two specimens probably belonging to Beloceras. The best specimen (Petter 1959, pl. 10, fig. 1, text-fig. 44a), with a conch diameter of $75 \mathrm{~mm}$, comes from 'Ride de l'Adrar' in the Tafilalt (Anti-Atlas) and was described as 'Beloceras tenuistriatum (d'Archiac \& 


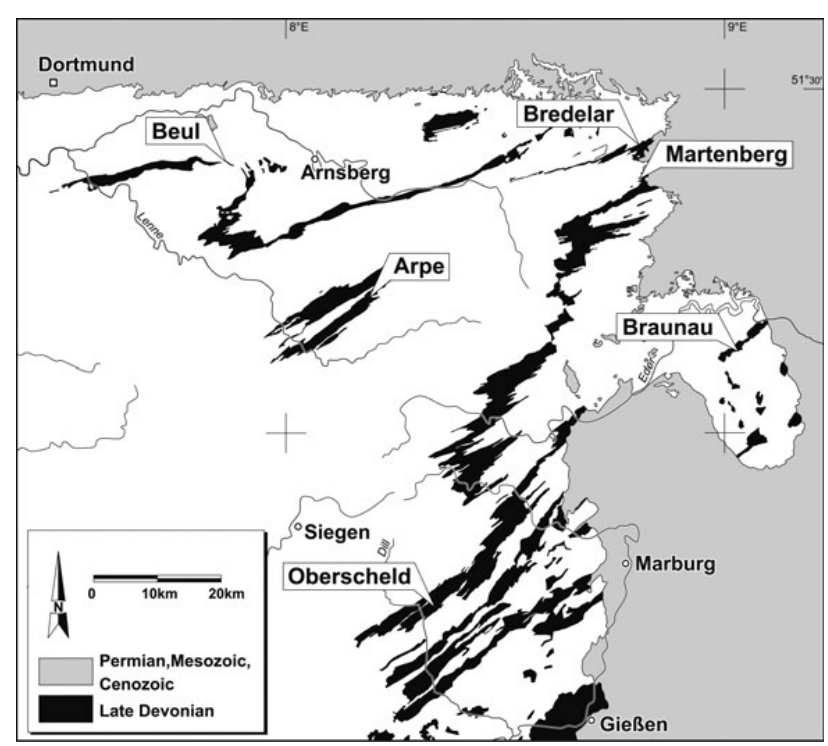

Figure 2. The main occurrences of Beloceras in the Rhenish Mountains.

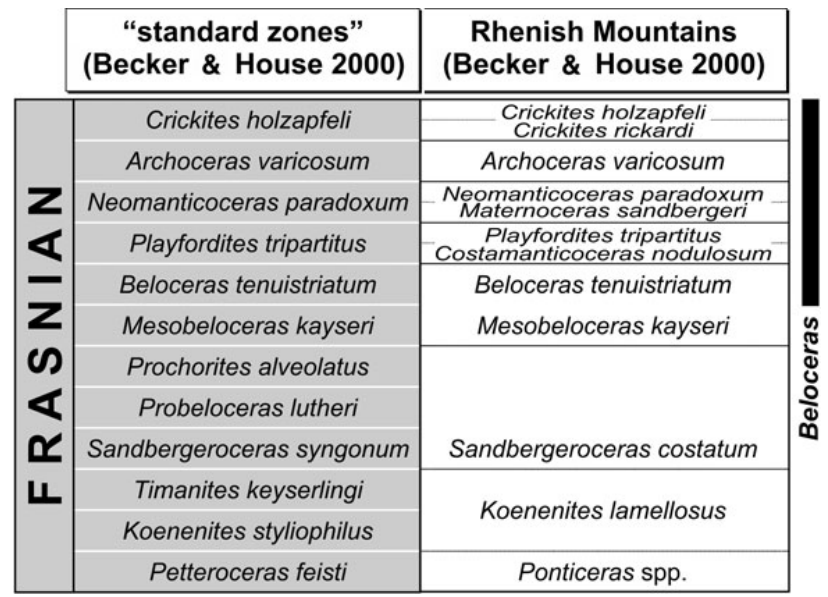

Figure 3. Frasnian ammonoid stratigraphy and the stratigraphic distribution of the genus Beloceras.

de Verneuil), 1837 var. ?' [sic!]. It was used by Yatskov (1990) to introduce the new species 'Beloceras (Beloceras) petterae Yatskov, 1990' based on the probably inaccurate suture line drawing provided by Petter (1959, p. 185, text-fig. 44a). The second specimen described by Petter (1959, pl. 10, fig. 2) as 'Beloceras cf. tenuistriatum (d'Archiac \& de Verneuil), 1837' [sic!] is a whorl fragment, which is difficult to interpret.

Additionally, Petter (1959, pl. 10, figs 3, 5, 6, 9, 10, text-fig. 44b) described a specimen, with a conch diameter of $69 \mathrm{~mm}$ as 'Beloceras kayseri (Holzapfel), 1882' from Themateni Znigui (Taouz region). This specimen belongs, according to its suture line and conch shape, to the genus Mesobeloceras.

Shotori Range: Yazdi (1999) as well as Wendt et al. (2005) reported 'Beloceras tenuistriatum' from eastern Iran; however, this material has not yet been described.
Yunnan: Chao (1956, pl. 1, figs 12-16) figured three specimens of his new species 'Beloceras acutum' from the Baoshan Block. They have a very narrow umbilicus and a suture line with four secondary prongs of the external lobe at $36 \mathrm{~mm}$ conch diameter. These characters put forward a strong case for its inclusion in the Beloceras; however, Yatskov (1990) used this species as the type species of his new genus Sinobeloceras.

Guangxi: Ruan (1981, pl. 9, figs 19, 22, text-fig. 20) published figures of poorly preserved specimens of a beloceratid, and the suture line can only be seen as a schematic representation. However, Yatskov (1990) based his new species 'Sinobeloceras ruani Yatskov, 1990' on these illustrations. The material may belong to 'Beloceras acutum Chao, 1956'.

Canning Basin: Teichert $(1941,1943)$ reported the presence of the genus Beloceras in the Canning Basin. Glenister (1958), in his monograph described two species of the family Beloceratidae, 'Mesobeloceras thomasi Glenister, 1958' and 'Beloceras sagittarium (Sandberger \& Sandberger, 1851)'. Yatskov (1990) identified the latter as his new species 'Mesobeloceras glenisteri Yatskov, 1990'. House (1971) figured the wrinkle layer of this species.

All these occurrences show that Beloceras has a stratigraphic position in the upper part of the Frasnian (Fig. 3) of the ammonoid stratigraphy proposed by Becker \& House (2000). The Beloceras tenuistriatum Zone was defined with the first entry of the genus. Occurrences of Beloceras in well-studied sections have been reported from the Martenberg near Adorf (House \& Ziegler 1977) in the classic German ammonoid zones I $\beta, \mathrm{I} \gamma$, and $\mathrm{I} \delta$ (i.e. correlating with the Beloceras tenuistriatum Zone to the Crickites holzapfeli Zone of the revised Frasnian zonation (Becker \& House 2000). Beloceras became extinct at the FrasnianFamennian boundary.

Material of B. sagittarium from the Thuringian Mountains has been dated with conodonts. Poorly preserved specimens from Schleiz (see appendix) derive from a limestone bed immediately below the Upper Kellwasser Horizon and belong in the Upper rhenana or the linguiformis Zone (Weyer et al. 2003). Specimens of 'B. tenuistriatum' (=B. petterae) from Ouidane Chebbi in the Anti-Atlas of Morocco have been dated and as a result of this they have been placed in Zone 6 (primus Zone) of the Frasnian composite standard (Belka et al. 1999).

\section{Material}

We studied material from four principal regions of Germany and Morocco, (1) the Eifel Mountains (locality Büdesheim), (2) the Rhenish Mountains (a number of localities including Beul, Bredelar, Martenberg, Oberscheld, Ense), (3) the Thuringian Mountains (localities Braunsberg and Vogelsberg), and (4) the Anti-Atlas. A total of 165 specimens have 


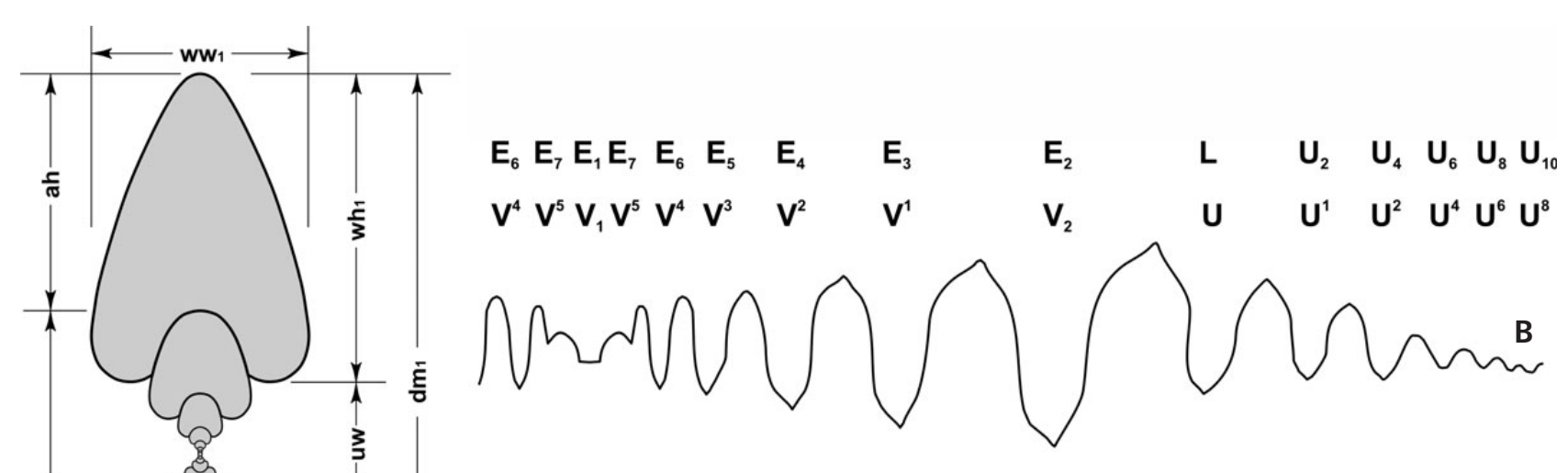

been studied, all of them are stored in the collection of the Museum für Naturkunde Berlin (see appendix).

\section{Systematic palaeontology}

The descriptions and illustrations follow the scheme proposed by Korn (2010) for Carboniferous ammonoids (Fig. 4). The terminology of the suture line was used according to Wedekind (1918) and Schindewolf (1929) but with some modifications (for a summary see Korn \& Klug 2002). The terminology of the suture lines of gephuroceratid ammonoids is still debated and the naming of the distinct sutural elements can be varied according to which suture terminology is used. Therefore, Miller et al. (1957, p. L19) stated for sutural formulas that "... if they are not readily understandable they do not serve a good purpose". However, sutural formulas, despite their shortcomings, still help to understand differences between ontogenetic traits and are used here to characterise the species.

Bogoslovsky (1969) separated two principal developmental processes of the external lobe (his V lobe):

(1) The external lobe is subdivided by an incision of its flanks, becoming secondary prongs. The formula of the external lobe is $\left(\mathrm{V}_{2} \mathrm{~V}_{1} \mathrm{~V}_{2}\right)$, proposed for Manticoceras, Beloceras, etc. Translated to the concept of Schindewolf (1929) this would be $\left(E_{2} E_{1} E_{2}\right)$; we use this $\left(E_{2} E_{1} E_{2}\right)$ system in the present study (Fig. 4).

(2) The external lobe is subdivided by the raising of a median saddle causing secondary prongs. The formula is then $\left(\mathrm{V}_{1} \mathrm{~V}_{1}\right)$, as proposed for Timanoceras. Bogoslovsky $(1957,1969)$ used this criterion for a separation of Timanoceras from the gephuroceratids and introduced the suborder Timanoceratina for this single genus. The validity of this taxon must be questioned; the putative difference in the development of the suture line is probably caused by different preservation and preparation techniques. As Clausen (1969) demonstrated, the pyritic phragmocones of Manticoceras specimens from Büdesheim would fall into this category.

Conch measurements, proportions, and growth rates are applied according to Korn \& Klug (2007), as they were used there for gephuroceratid ammonoids (Fig. 4).

The abbreviations used in the text are: conch diameter (dm), whorl width (ww), whorl height (wh), umbilical width (uw) $=\mathrm{dm}_{1}-\mathrm{wh}_{1}-\mathrm{wh}_{2}$, apertural height (ah) $=$ $\mathrm{dm}_{1}-\mathrm{dm}_{2}$. Conch proportions (growth rates) and expansion rates were calculated in the following way by using the three basic conch parameters: conch width index $(\mathrm{CWI})=\mathrm{ww}_{1} / \mathrm{dm}_{1}$, whorl width index $(\mathrm{WWI})=\mathrm{ww}_{1} / \mathrm{wh}_{1}$, umbilical width index $(\mathrm{UWI})=\mathrm{uw} / \mathrm{dm}_{1}$ or $\left(\mathrm{dm}_{1}-\mathrm{wh}_{1}-\right.$ $\left.\mathrm{wh}_{2}\right) / \mathrm{dm}_{1}$, whorl expansion rate $(\mathrm{WER})=\left(\mathrm{dm}_{1} / \mathrm{dm}_{2}\right)^{2}$ or $\left[\mathrm{dm}_{1} /\left(\mathrm{dm}_{1}-\mathrm{ah}\right)\right]^{2}$, imprint zone rate $($ IZR $)=\mathrm{wh}_{1}-\mathrm{ah} / \mathrm{wh}_{1}$ or $\left[\mathrm{wh}_{1}-\left(\mathrm{dm}_{1}-\mathrm{dm}_{2}\right)\right] / \mathrm{wh}_{1}$.

Suborder Gephuroceratina Ruzhencev, 1957

Included superfamilies. -

Gephurocerataceae Frech, 1897

Timanocerataceae Ruzhencev, 1957 [synonym of Gephurocerataceae]

Belocerataceae Hyatt, 1884

Superfamily Belocerataceae Hyatt, 1884

Included families. -

Acanthoclymeniidae Schindewolf, 1955

Beloceratidae Hyatt, 1884 
Eobeloceratidae Becker \& House, 1994 [synonym of Beloceratidae]

Nordiceratidae Korn \& Klug, 2002 [synonym of Beloceratidae]

Family Beloceratidae Hyatt, 1884

Included genera. - Naplesites Yatskov, 1990,

Anabeloceras Clarke, 1899 [nomen nudum; synonym of Naplesites],

Chaoceras Yatskov, 1990 [synonym of Naplesites],

Merzougites Korn \& Klug, 2002,

Eobeloceras Schindewolf, 1936,

Mesobeloceras Glenister, 1958,

Atopobeloceras Yatskov, 1990 [probably a synonym of Mesobeloceras],

Sinobeloceras Yatskov, 1990 [probably a synonym of Beloceras],

Beloceras Hyatt, 1884,

Ceratobeloceras House \& Kirchgasser, 1985 [synonym of Beloceras],

Idiobeloceras Yatskov, 1990 [synonym of Beloceras], Nordiceras Bogoslovsky, 1955 [synonym of Beloceras].

\section{Genus Beloceras Hyatt, 1884}

Type species. - Goniatites sagittarius Sandberger \& Sandberger, 1851, p. 77.

Included species. acutum: Beloceras acutum Chao, 1956, p. 103; Yunnan. bogoslovskyi: Mesobeloceras bogoslovskyi Yatskov, 1990, p. 47; Altay.

gallicum: Beloceras (Beloceras) gallicum Yatskov, 1990, p. 48; Montagne Noire.

glenisteri: Mesobeloceras glenisteri Yatskov, 1990, p. 47; Canning Basin.

jorfense: Beloceras jorfense sp. nov.; Anti-Atlas.

multilobatum: Ammonites multilobatus Beyrich, 1837, p. 33; Rhenish Mountains [non Ammonites multilobatus Bronn, 1832].

petterae: Beloceras (Beloceras) petterae Yatskov, 1990, p. 48; Saoura Valley.

praecursor: Beloceras praecursor Frech, 1902, p. 61; Carnic Alps.

ruani: Sinobeloceras ruani Yatskov, 1990, p. 45; Guangxi. sagittarium: Goniatites sagittarius Sandberger \& Sandberger, 1851, p. 77; Rhenish Mountains.

schulzi: Ceratobeloceras schulzi House \& Kirchgasser, 1985, p. 9; Montagne Noire.

shidianense: Beloceras shidianensis Yang, 1984, p. 33; Yunnan. stenumbilicatum: Beloceras stenumbilicatum Bogoslovsky, 1958, p. 121; Altay.

tenuistriatum: Goniatites tenuistriatus d'Archiac \& de Verneuil, 1842, p. 343; Rhenish Mountains.

termieri: Sinobeloceras termieri Yatskov, 1990, p. 45; Anti-Atlas.

timanicum: Prolecanites timanicus Holzapfel, 1899, p. 47; Timan.

webbelense: Beloceras webbelense sp. nov.; Rhenish Mountains.

Discussion. - The genus Beloceras is understood here as including species with an extremely discoidal, subinvolute to involute conch and an adult suture line with at least four secondary prongs of the external lobe. Mesobeloceras has a wider umbilicus than Beloceras, but it is the latter character in particular that separates Beloceras from Mesobeloceras, which possesses only three secondary prongs.

There is an obvious morphological evolution within the family Beloceratidae; the closure of the umbilicus is paralleled by the increase of sutural elements. Another trend can be seen in the shape of the sutural elements, particularly in the secondary prongs of the external lobes. These are $\mathrm{V}$-shaped and separated by triangular saddles in Mesobeloceras, producing a zigzag course of the suture line. The less advanced representatives of Beloceras, such as $B$. webbelense and $B$. petterae are similar in this respect, but those species with increasing numbers of lobes (B. sagittarium, B. stenumbilicatum) possess lanceolate lobes and tectiform saddles. Finally, weakening of the umbilical rim, which is very prominent within this genus, can be seen in species of Beloceras.

At the moment it cannot be fully verified if independent lineages are present in Beloceras, but the conch shape and configuration of the suture line suggest that the taxon is monophyletic. Further studies will show if the genus is represented by endemic species and if the morphological evolution within the genus reflects the stratigraphic occurrence of the species.

\section{Beloceras sagittarium (Sandberger \& Sandberger, 1851)}

Figures 5C, D, 6-10

* 1851 Goniatites sagittarius Sandberger \& Sandberger, p. 77 , pl. 4, fig. 3 .

non 1851 Goniatites sagittarius Sandberger \& Sandberger, pl. 4 , fig. $3 \mathrm{c}-\mathrm{e}$. [= Beloceras tenuistriatum (d'Archiac \& de Verneuil, 1842)]

1931 Beloceras multilobatum. - Matern, p. 76.

non 1958 Beloceras sagittarium. - Bogoslovsky, p. 119, pl. 6, figs 3, 4, pl. 7, fig. 1. [= Beloceras bogoslovskyi (Yatskov, 1990)] 
non 1958 Beloceras sagittarium. - Glenister, p. 85, pl. 5, fig. 12 , pl. 10, fig. 7, pl. 13, figs 1-5, pl. 14, figs $1-8$. [= Beloceras glenisteri (Yatskov, 1990)]

non 1969 Beloceras sagittarium. - Bogoslovsky, p. 299, text-fig. 101d, 10a-zh, pl. 27, figs 7, 8, pl. 28. [=Beloceras bogoslovskyi (Yatskov, 1990)]

non 1971 Beloceras sagittarium. - House, p. 24, pl. 1, fig. 4. [= Beloceras glenisteri (Yatskov, 1990)]

1991 Beloceras cf. sagittarium $\rightarrow$ Beloceras subacutum.Clausen in Clausen et al., p. 32, text-fig. 5C, pl. 13, fig. 4,5 .

Holotype. - Specimen MB.C.4501 (Dannenberg Coll.); Museum für Naturkunde Berlin.

Type locality and horizon. - Sessacker near Oberscheld; red Frasnian cephalopod limestones.

Material. - Specimens from four principal areas in Germany are available for study:

(1) Ten pyritized specimens (7-25 $\mathrm{mm}$ in conch diameter) and one calcareous fragment of a phragmocone which is about $120 \mathrm{~mm}$ in diameter from the Eifel Mountains (Büdesheim). All the specimens are preserved as internal moulds with parts of the body chamber preserved.

(2) Two specimens (Denckmann 1900 and 1902 Coll.), with conch diameters of 46 and $117 \mathrm{~mm}$, from the northern margin of the Rhenish Mountains (Beul near Eisborn). These specimens are embedded in grey or reddish cephalopod limestone; shell remains are preserved. One specimen (Mempel Coll.) with a conch diameter of $42 \mathrm{~mm}$ comes from Arpe.

(3) Twelve specimens from the eastern margin of the Rhenish Mountains besides the holotype: 5 specimens (Müller \& Denckmann Coll.) which are between 37 and $86 \mathrm{~mm}$ in $\mathrm{dm}$ from the Charlottenzug Mine near Bredelar; three specimens (Dannenberg, Lotz 1901 Coll.) between 77 and $115 \mathrm{~mm}$ in dm from the Seßacker near Oberscheld; one specimen with a diameter of $50 \mathrm{~mm}$ from the Staatliche
Grube near Oberscheld; two specimens (Denckmann 1888 Coll.) measuring 100 and $102 \mathrm{~mm}$ in $\mathrm{dm}$ from the Schmidt quarry near Braunau (Kellerwald). Most of the specimens were collected during the period when the ironstone mines in the Rhenish Mountains were still being worked. They are often preserved with shell remains in red cephalopod limestone or haematitic iron ore.

(4) Thirty-five specimens (ranging from $35-135 \mathrm{~mm}$ in conch diameter) from the Thuringian Mountains: 19 specimens from dark-grey limestones of the Braunsberg near Tegau (Schultz 1967 Coll.); 10 specimens up to $129 \mathrm{~mm}$ in diameter from red cephalopod limestones of the Vogelsberg quarry near Göschitz (Bartzsch \& Weyer 1985 Coll.), and six fragments (Bartzsch \& Weyer 1995 Coll.) from Schleiz.

Diagnosis. - Species of Beloceras with involute conch (uw/dm $=0.10$ in stages larger than $50 \mathrm{~mm}$ diameter). Suture line with six or seven secondary prongs of the external lobe, a lanceolate lateral lobe, and six or more umbilical lobes on the flanks at a conch diameter of $60 \mathrm{~mm}$; formula of the ventral suture line in this growth stage $\left(E_{2} E_{3} E_{4} E_{5} E_{6} E_{7}\right.$ $\left.\mathrm{E}_{1} \mathrm{E}_{7} \mathrm{E}_{6} \mathrm{E}_{5} \mathrm{E}_{4} \mathrm{E}_{3} \mathrm{E}_{2}\right) \mathrm{LU}_{2} \mathrm{U}_{4} \mathrm{U}_{6} \mathrm{U}_{8} \mathrm{U}_{10} \mathrm{U}_{12}$. All external lobes are lanceolate, the $\mathrm{E}_{4}, \mathrm{E}_{5}$, and $\mathrm{E}_{6}$ lobes are very narrow and deep; three or four of the larger saddles (between the $\mathrm{L}$ lobe and the $\mathrm{E}_{4}$ lobe) are tectiform. The adult suture line has an increasing number of umbilical lobes.

Description of material from the Rhenish Mountains. - The type specimen (MB.C.4501; Dannenberg Collection) of 'Goniatites sagittarius Sandberger \& Sandberger, 1851' in the Museum für Naturkunde, Berlin has a conch diameter of approximately $120 \mathrm{~mm}$ and is fully septate (Fig. 5C). The specimen comes from Sessacker near Oberscheld and is not as well preserved as would be expected from Sandberger \& Sandberger's (1850-1856, pl. 4, fig. 3) beautiful illustration (Fig. 5D). It is strongly corroded with portions of the outer flanks and venter as well as the umbilical mar-

Table 1. Conch ontogeny (Figs 8, 9) of Beloceras sagittarium (Sandberger \& Sandberger, 1851) from Büdesheim (up to 18 mm dm) and the Rhenish and Thuringian Mountains (larger stages).

\begin{tabular}{|c|c|c|c|}
\hline $\mathrm{dm}$ & conch shape & whorl cross section shape & aperture \\
\hline $1.5 \mathrm{~mm}$ & $\begin{array}{l}\text { thinly discoidal; subevolute } \\
\text { (ww/dm } \sim 0.38 ; \text { uw/dm } \sim 0.39 \text { ) }\end{array}$ & weakly depressed; weakly embracing (ww/wh 1.05; IZR 0.12) & high (WER 2.20) \\
\hline $4 \mathrm{~mm}$ & $\begin{array}{l}\text { extremely discoidal; subevolute } \\
\text { (ww/dm } \sim 0.25 ; \mathrm{uw} / \mathrm{dm} \sim 0.40 \text { ) }\end{array}$ & weakly compressed; weakly embracing (ww/wh $\sim 0.80 ; \mathrm{IZR} \sim 0.14$ ) & high (WER 2.15) \\
\hline $8 \mathrm{~mm}$ & $\begin{array}{l}\text { extremely discoidal; subevolute } \\
\text { (ww/dm } \sim 0.25 ; \mathrm{uw} / \mathrm{dm} \sim 0.35 \text { ) }\end{array}$ & weakly compressed; moderately embracing (ww/wh $\sim 0.60 ;$ IZR $\sim 0.20$ ) & high (WER 2.25) \\
\hline $18 \mathrm{~mm}$ & $\begin{array}{l}\text { extremely discoidal; subinvolute } \\
\text { (ww/dm } \sim 0.25 ; \text { uw/dm } \sim 0.17 \text { ) }\end{array}$ & strongly compressed; strongly embracing (ww/wh 0.45; IZR 0.32) & extremely high (WER 2.55) \\
\hline $50 \mathrm{~mm}$ & $\begin{array}{l}\text { extremely discoidal; involute } \\
\text { (ww/dm } \sim 0.18 ; \text { uw/dm } \sim 0.10 \text { ) }\end{array}$ & strongly compressed; strongly embracing (ww/wh $\sim 0.35 ; \mathrm{IZR} \sim 0.35$ ) & extremely high $(\mathrm{WER} \sim 2.55)$ \\
\hline $100 \mathrm{~mm}$ & $\begin{array}{l}\text { extremely discoidal; involute } \\
\text { (ww/dm } \sim 0.18 ; \mathrm{uw} / \mathrm{dm} \sim 0.10 \text { ) }\end{array}$ & strongly compressed; strongly embracing (ww/wh $\sim 0.30 ; \mathrm{IZR} \sim 0.35$ ) & very high $($ WER 2.40) \\
\hline
\end{tabular}


gin missing; it does not provide a complete picture of the suture line. The shell surface is also poorly preserved, but some shell remains show that there are five strong spiral lines on the outer flank. It is difficult to obtain conch measurements from this corroded specimen, but it can be estimated that the umbilicus was about one tenth of the conch diameter.

The best-preserved available specimen is MB.C.19180 (Denckmann 1902 Coll.; Fig. 6A) from Beul ('Beuel b. Balve' according to the label). It has a conch diameter of $117 \mathrm{~mm}$ and is nearly complete, being extremely discoidal and involute $(\mathrm{ww} / \mathrm{dm}=0.17 ; \mathrm{uw} / \mathrm{dm}=0.10)$ with a very high aperture (WER $=2.40$ ). A faint rim accompanies the umbilical seam and the umbilical wall is shallow and slightly concave. The conch is widest in the midflank area, from where the flanks converge slowly towards the umbilicus and the subacute venter. Most of the specimen is covered by the shell, which appears to be completely smooth. Faint growth lines can only be seen on the outer flanks.

Specimen MB.C.19182 (Denckmann 1888 Coll.) from 'Schmidt's Steinbruch am Kalkofen b. Braunau' is a fragment of the largest available specimen. The phragmocone is nearly completely preserved at $100 \mathrm{~mm}$ in diameter, and another half a volution of the phragmocone is visible in parts but the body chamber is missing. The total size of the specimen has been estimated to be approximately $250 \mathrm{~mm}$ in diameter. Shell remains are not preserved, but the specimen displays parts of the suture line characteristic for an advanced species of Beloceras.

Specimen MB.C.4504 (Denckmann Coll.) from the Charlottenzug Mine near Bredelar is a fragment of a phragmocone approximately $80 \mathrm{~mm}$ in diameter and allows for the study of parts of the suture line. At a whorl height of about $36 \mathrm{~mm}$, the suture line shows seven secondary external lobes, all lanceolate with the tendency to become narrower towards the venter. The saddles between the first external and lateral lobe as well as between the first and fourth external lobes are tectiform, the saddles between the fourth and the seventh external lobe are rounded.
A specimen with a conch diameter of $50 \mathrm{~mm}$ (MB.C.4502; Hubach Collection) labelled 'Staatliche Grube, Oberscheld' is the specimen with the best preserved shell ornament in the Berlin collection (Fig. 6B, C). It is preserved in haematitic iron ore and possesses extremely fine growth lines, which extend almost linearly across the flanks. They form a low projection on the outer flank, where they become stronger, and turn back to form a very deep and narrow ventral sinus. On the tabulate venter they are lamellar, being arranged in distances of $0.2 \mathrm{~mm}$. The umbilical wall is very shallow with a faint rim near the umbilical seam.

The sectioned specimen MB.C.19175 (Fig. 9) shows, at a conch diameter of $67 \mathrm{~mm}$ the characteristic shape of the umbilicus. The umbilical wall is very shallow and possesses a weak umbilical rim at the umbilical seam.

Description of material from the Thuringian Mountains. Specimen MB.C.19194 (Bartzsch \& Weyer 1985 Coll.) from the Vogelsberg near Göschitz is the best preserved specimen from that locality (Fig. 7). It is slightly deformed and has a conch diameter of $106 \mathrm{~mm}$. Most of this specimen represents the phragmocone, and only a very short portion of the body chamber is preserved. The conch has the appearance of a flat disc $(\mathrm{ww} / \mathrm{dm}=0.15)$ and is involute (uw/dm $=0.10$ ) with an extremely high aperture (WER = 2.63). The umbilical margin is broadly rounded and separates the umbilical wall from the flanks, which converge to the narrowly rounded, almost subacute venter. Shell remains are present in the specimen, but their preservation is poor because of the strong pressure solution of its surface.

The suture line of this specimen (Fig. 8C) was drawn where the whorl height is $34 \mathrm{~mm}$, corresponding to a conch diameter of about $66 \mathrm{~mm}$. Six secondary prongs of the external lobe are present here; all are lanceolate and show a tendency to become narrower towards the venter. The lateral lobe is lanceolate with nearly parallel flanks, and the six visible umbilical lobes are V-shaped. The

Table 2. Conch dimensions (in $\mathrm{mm}$ ) and proportions for reference specimens of Beloceras sagittarium (Sandberger \& Sandberger, 1851) from Büdesheim.

\begin{tabular}{|c|c|c|c|c|c|c|c|c|c|c|}
\hline & $\mathrm{dm}$ & ww & wh & uw & ah & $\mathrm{ww} / \mathrm{dm}$ & ww/wh & $\mathrm{uw} / \mathrm{dm}$ & WER & IZR \\
\hline MB.C.22003.1 & 17.7 & 4.6 & 9.7 & 3.0 & 6.6 & 0.26 & 0.47 & 0.17 & 2.53 & 0.32 \\
\hline MB.C.22004.2 & 11.0 & 2.9 & 4.9 & 3.4 & 3.8 & 0.26 & 0.59 & 0.31 & 2.31 & 0.23 \\
\hline MB.C.22004.4 & 7.6 & 1.8 & 2.9 & 2.9 & 2.5 & 0.23 & 0.61 & 0.38 & 2.24 & 0.13 \\
\hline \multirow[t]{6}{*}{ MB.C.22003.3 } & 6.92 & 1.75 & 2.74 & 2.46 & 2.22 & 0.25 & 0.64 & 0.36 & 2.17 & 0.19 \\
\hline & 4.70 & 1.27 & 1.72 & 1.83 & 1.48 & 0.27 & 0.74 & 0.39 & 2.13 & 0.14 \\
\hline & 3.22 & 0.91 & 1.15 & 1.30 & 1.00 & 0.28 & 0.79 & 0.40 & 2.11 & 0.13 \\
\hline & 2.22 & 0.67 & 0.77 & 0.89 & 0.70 & 0.30 & 0.86 & 0.40 & 2.13 & 0.09 \\
\hline & 1.52 & 0.58 & 0.56 & 0.59 & 0.50 & 0.38 & 1.04 & 0.39 & 2.21 & 0.11 \\
\hline & 1.02 & 0.56 & 0.38 & 0.28 & 0.32 & 0.54 & 1.48 & 0.27 & 2.14 & 0.14 \\
\hline
\end{tabular}




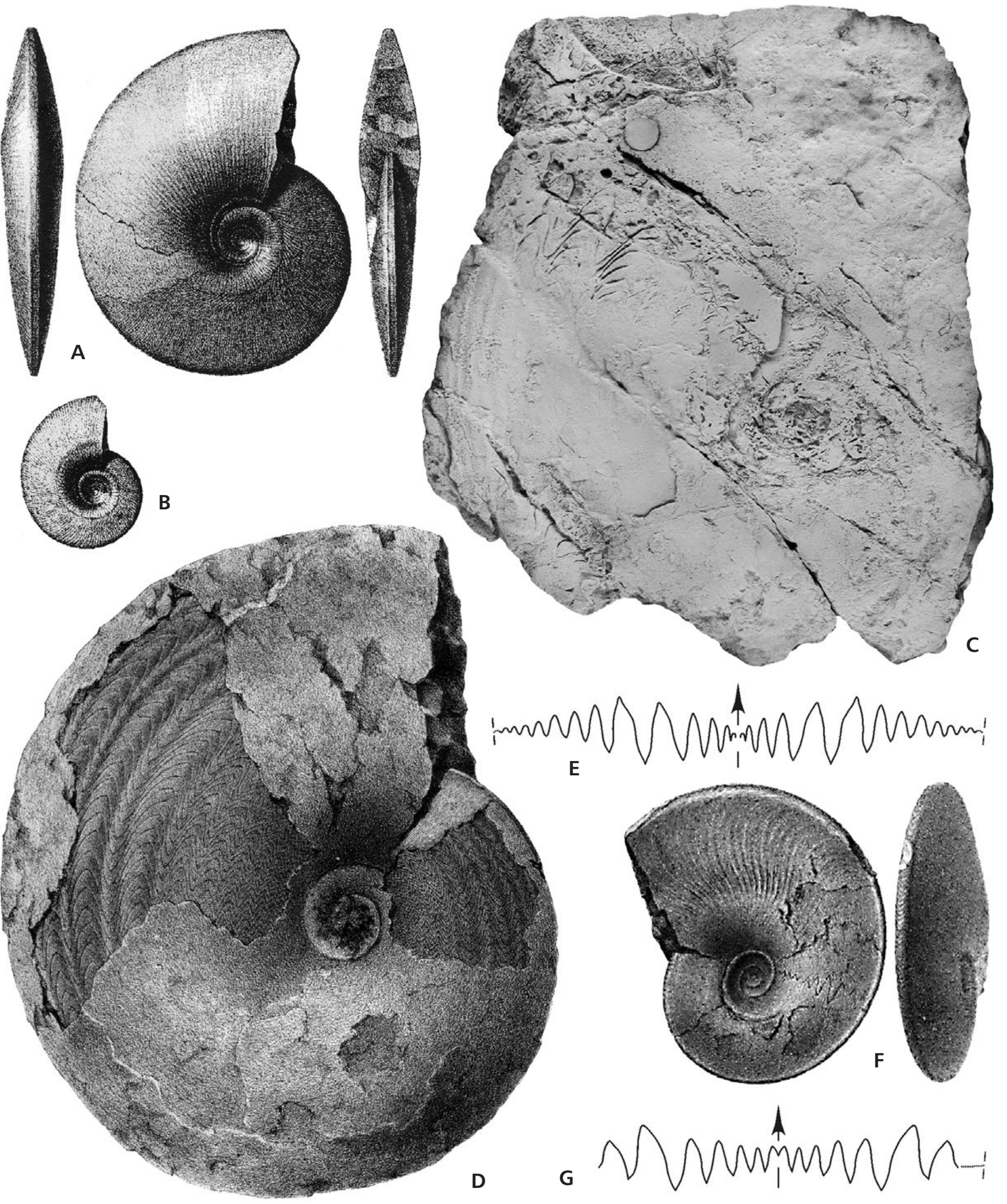

Figure 5. Reproductions of historical specimens of Beloceras. • A, B - Beloceras tenuistriatum (d'Archiac \& de Verneuil, 1842); 'Goniatites tenuistriatus' figured by d'Archiac \& de Verneuil (1842, pl. 26, fig. 7, 8). C - Beloceras sagittarium (Sandberger \& Sandberger, 1851), lectotype MB.C.4501 (Dannenberg Coll.) from Sessacker near Oberscheld; $\times 1.0 . \bullet D-$ Beloceras sagittarium (Sandberger \& Sandberger, 1851); 'Goniatites sagittarius' figured by Sandberger \& Sandberger (1850-1856, pl. 4, fig. 3). E, F - Beloceras tenuistriatum (d'Archiac \& de Verneuil, 1842); 'Goniatites sagittarius' figured by Sandberger \& Sandberger (1850-1856, pl. 4, fig. 3c, e). • G - 'Ammonites multilobatus' figured by Beyrich (1837, pl. 1, fig. 9). 

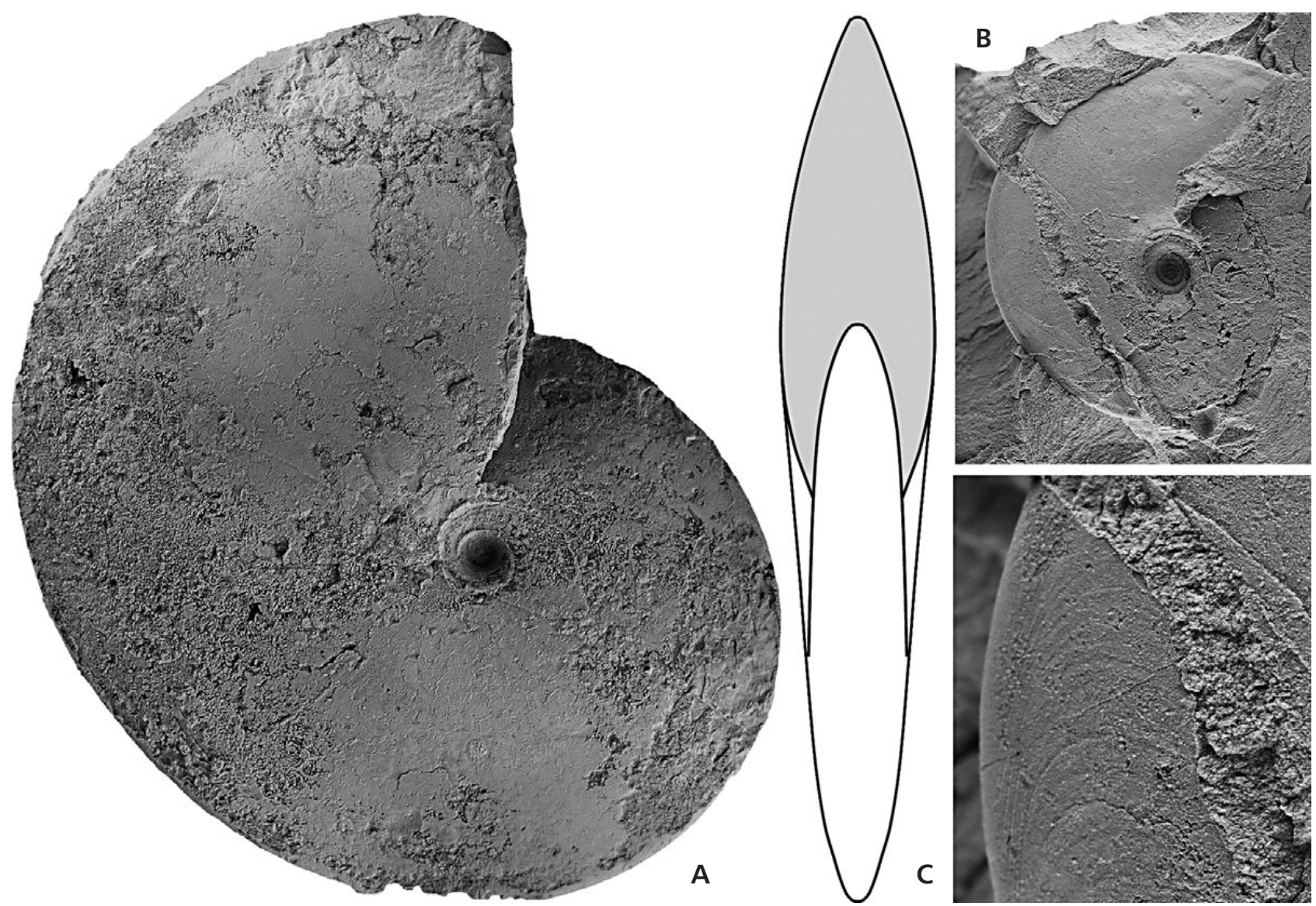

Figure 6. Beloceras sagittarium (Sandberger \& Sandberger, 1851) from the Rhenish Mountains. • A - specimen MB.C.19180 (Denckmann 1902 Coll.) from Beul; $\times$ 1.0. $\bullet$ B - specimen MB.C.4502 (Hubach Coll.) from the Staatliche Grube, Oberscheld; $\times 1.0 . \bullet C-$ the same specimen, enlargement $\times 4.0$.

Table 3. Conch dimensions (in $\mathrm{mm}$ ) and proportions for reference specimens of Beloceras sagittarium (Sandberger \& Sandberger, 1851) from the Rhenish Mountains.

\begin{tabular}{lcccccccccc}
\hline & $\mathrm{dm}$ & $\mathrm{ww}$ & $\mathrm{wh}$ & $\mathrm{uw}$ & $\mathrm{ah}$ & ww/dm & ww/wh & uw/dm & WER & IZR \\
\hline MB.C.19180 & 116.6 & 20.1 & 64.3 & 11.6 & 41.3 & 0.17 & 0.31 & 0.10 & 2.40 & 0.36 \\
MB.C.19182 & 102.2 & 21.8 & 58.4 & 10.5 & - & 0.21 & 0.37 & 0.10 & - & - \\
MB.C.19176 & 98.3 & 20.0 & 54.6 & 10.5 & - & 0.20 & 0.37 & 0.11 & - & - \\
MB.C.19171 & 84.1 & 13.6 & 47.7 & 9.1 & 31.3 & 0.16 & 0.29 & 0.11 & 2.54 & 0.34 \\
MB.C.19173 & 66.4 & 11.1 & 38.3 & 6.2 & 24.8 & 0.17 & 0.29 & 0.09 & 2.54 & 0.35 \\
MB.C.19174 & 35.0 & 8.8 & 19.5 & 3.5 & - & 0.25 & 0.45 & 0.10 & - & - \\
MB.C.19175 & 72.3 & 11.5 & 41.2 & 6.1 & 27.7 & 0.16 & 0.28 & 0.08 & 2.63 & 0.33 \\
& 44.6 & 8.5 & 25.1 & 4.3 & 16.8 & 0.19 & 0.34 & 0.10 & 2.57 & 0.33 \\
& 27.8 & 5.8 & 15.2 & 3.5 & 10.2 & 0.21 & 0.38 & 0.13 & 2.50 & 0.33 \\
& 17.6 & 4.4 & 9.0 & 3.1 & 6.6 & 0.25 & 0.49 & 0.18 & 2.58 & 0.26 \\
& 10.9 & 2.79 & 5.47 & 2.55 & 4.19 & 0.26 & 0.51 & 0.23 & 2.63 & 0.23 \\
& 6.74 & 1.87 & 2.91 & 2.00 & 2.37 & 0.28 & 0.64 & 0.30 & 2.38 & 0.18 \\
& 4.36 & 1.42 & 1.82 & 1.50 & 1.61 & 0.33 & 0.78 & 0.34 & 2.52 & 0.12 \\
& 2.75 & 0.94 & 1.04 & 1.00 & 0.92 & 0.34 & 0.91 & 0.36 & 2.26 & 0.11 \\
& 1.83 & 0.82 & 0.71 & 0.67 & 0.64 & 0.45 & 1.15 & 0.37 & 2.35 & 0.11 \\
\hline
\end{tabular}


three saddles between the lateral lobe and the $\mathrm{E}_{6}$ lobe are tectiform.

The cross section of specimen MB.C.19199 (Fig. 8A) with a conch diameter of $129 \mathrm{~mm}$ shows the transformation into the adult stage, in which the whorl cross section becomes wider $(\mathrm{ww} / \mathrm{dm}=0.20$; Table 4$)$ and the umbilical wall steeper in comparison with the inner whorls. The whorl cross section has here a flattened triangular shape with strongly converging flanks and a very narrow, subacute venter.

The largest of the Thuringian specimens is MB.C.19183 (Schultz 1967 Coll.); it is a fully septate individual with a $135 \mathrm{~mm}$ conch diameter and showing the adult suture line. Unfortunately, the specimen has suffered during previous preparation attempts (it was too deeply polished), so that the conch shape has altered. The suture line (Fig. 8E), however, could be drawn at the maximum diameter and possesses seven lanceolate secondary prongs of the external lobe and an $8^{\text {th }}$, incipient one. Ten umbilical lobes are present on the inner flank.

Description of material from Büdesheim. - The ontogenetic development of the material shows several trends. The initial stage $(1 \mathrm{~mm}$ in $\mathrm{dm})$ is thickly discoidal $(\mathrm{ww} / \mathrm{dm}=0.54)$, but the conch becomes rapidly more slender, being extremely discoidal already at $2 \mathrm{~mm}$ in $\mathrm{dm}(\mathrm{ww} / \mathrm{dm}=0.30)$. All larger stages up to $18 \mathrm{~mm}$ in dm range between 0.23 and 0.28 . The umbilicus is rather wide between 2 and $5 \mathrm{~mm}$ in $\mathrm{dm}(\mathrm{uw} / \mathrm{dm}=0.40)$ but thereafter rapidly becomes narrower (uw/dm $=0.17$ at $18 \mathrm{~mm}$ in $\mathrm{dm}$ ). The whorl expansion rate is, with WER $=2.10-2.20$, rather stable up to $7 \mathrm{~mm}$ in $\mathrm{dm}$ and then increases to a value of 2.50 at $18 \mathrm{~mm}$ in $\mathrm{dm}$.

One small specimen (MB.C.22003.3; $7 \mathrm{~mm}$ in $\mathrm{dm}$ ) was

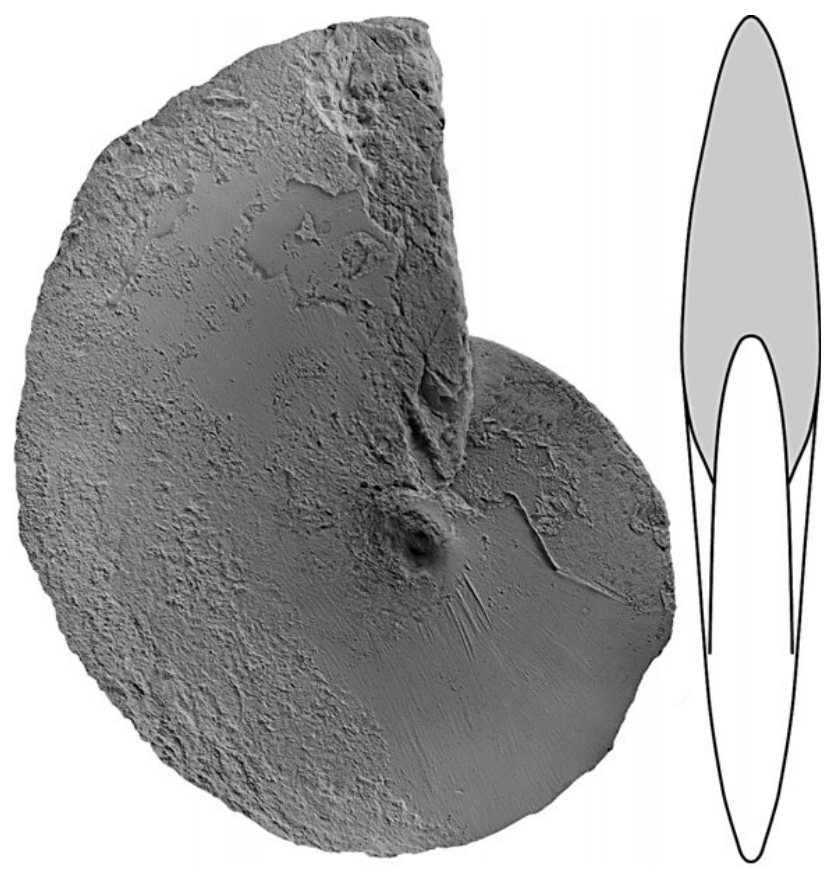

Figure 7. Beloceras sagittarium (Sandberger \& Sandberger, 1851) from the Thuringian Mountains, specimen MB.C.19194 (Bartzsch \& Weyer 1985 Coll.) from the Vogelsberg near Göschitz; $\times 0.8$.

sectioned (Fig. 10A). It has three and a half whorls, which show a rapid ontogenetic transformation in their cross section. While the first whorl (up to $1 \mathrm{~mm}$ in $\mathrm{dm}$ ) is kidney-shaped in the section, the second whorl is (up to $2.2 \mathrm{~mm}$ in $\mathrm{dm}$ ) circular or slightly oval and compressed. The flanks become flattened in the third whorl, and at the largest visible diameter, the venter is slightly applanate. Specimen MB.C.22003.1 is the largest one within the

Table 4. Conch dimensions (in $\mathrm{mm}$ ) and proportions for reference specimens of Beloceras sagittarium (Sandberger \& Sandberger, 1851) from the Thuringian Mountains.

\begin{tabular}{|c|c|c|c|c|c|c|c|c|c|c|}
\hline & $\mathrm{dm}$ & ww & wh & uw & ah & ww/dm & ww/wh & uw/dm & WER & IZR \\
\hline MB.C.19199 & 129.0 & 25.8 & 70.8 & 14.7 & 47.8 & 0.20 & 0.36 & 0.11 & 2.52 & 0.33 \\
\hline MB.C.19196 & 106.2 & 15.8 & 61.8 & 9.8 & 39.2 & 0.15 & 0.26 & 0.09 & 2.51 & 0.37 \\
\hline MB.C.19194 & 105.7 & 15.7 & 55.3 & 10.1 & 41.3 & 0.15 & 0.28 & 0.10 & 2.63 & 0.33 \\
\hline MB.C.19186 & 78.2 & 10.9 & 44.4 & 7.8 & - & 0.14 & 0.25 & 0.10 & - & - \\
\hline MB.C.19184 & 59.3 & 9.6 & 30.0 & 5.5 & - & 0.16 & 0.32 & 0.09 & - & - \\
\hline MB.C.19185 & 35.9 & 7.6 & 17.8 & 3.9 & - & 0.21 & 0.43 & 0.11 & - & - \\
\hline \multirow[t]{8}{*}{ MB.C.19192 } & 90.8 & 16.5 & 51.2 & 8.7 & 33.2 & 0.18 & 0.32 & 0.10 & 2.48 & 0.35 \\
\hline & 57.7 & 10.5 & 31.0 & 7.5 & 19.8 & 0.18 & 0.34 & 0.13 & 2.32 & 0.36 \\
\hline & 37.9 & 7.0 & 19.2 & 5.8 & 12.9 & 0.18 & 0.36 & 0.15 & 2.31 & 0.32 \\
\hline & 25.0 & 5.0 & 13.0 & 4.0 & 9.1 & 0.20 & 0.38 & 0.16 & 2.46 & 0.30 \\
\hline & 15.9 & 3.5 & 8.0 & 3.5 & 6.0 & 0.22 & 0.43 & 0.22 & 2.59 & 0.24 \\
\hline & 9.88 & 2.32 & 4.44 & 2.93 & 3.61 & 0.23 & 0.52 & 0.30 & 2.48 & 0.19 \\
\hline & 6.27 & 1.71 & 2.50 & 2.28 & 2.05 & 0.27 & 0.68 & 0.36 & 2.21 & 0.18 \\
\hline & 4.21 & 1.09 & 1.48 & - & 1.27 & 0.26 & 0.74 & - & 2.05 & 0.14 \\
\hline
\end{tabular}



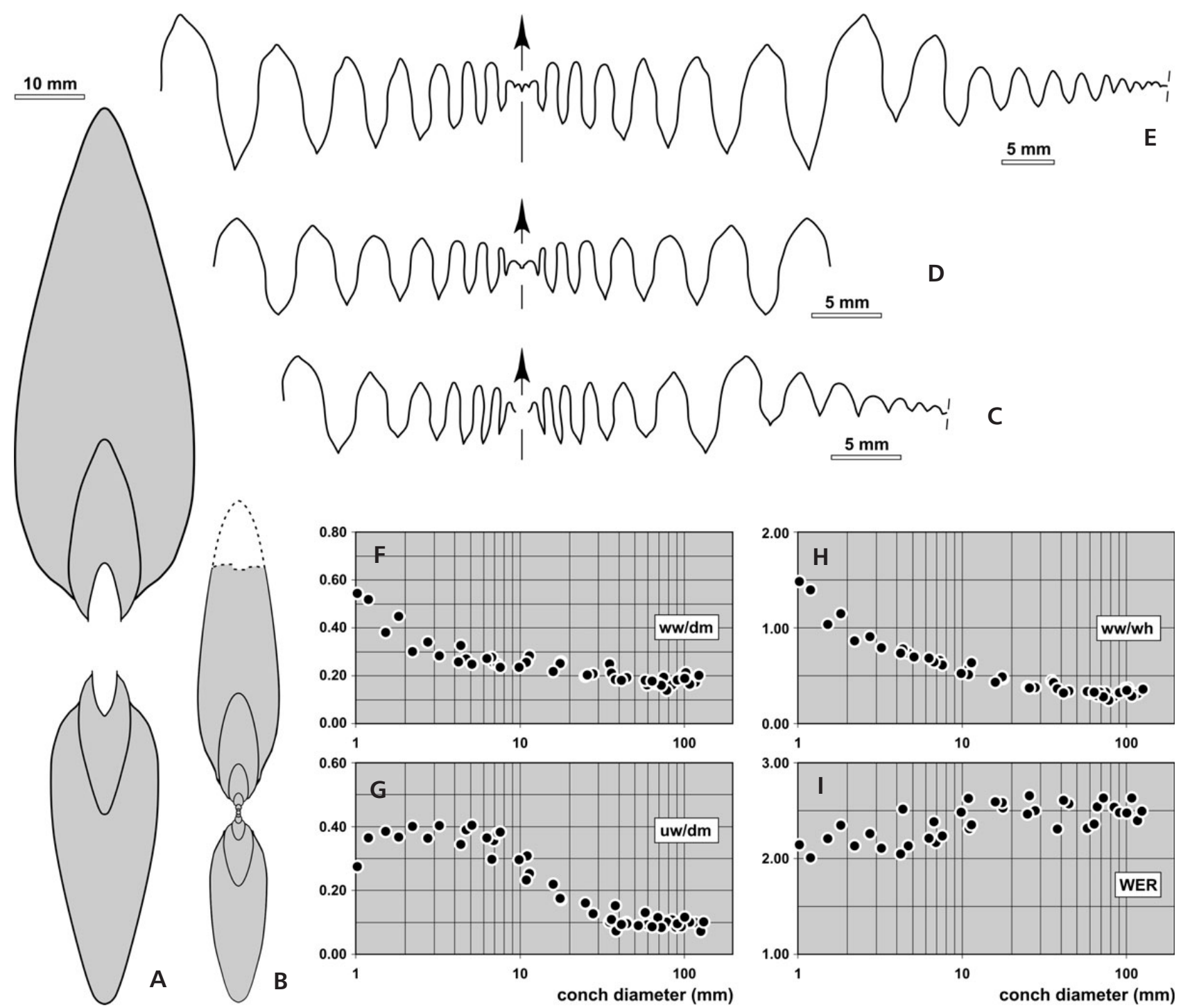

Figure 8. Beloceras sagittarium (Sandberger \& Sandberger, 1851) from the Rhenish Mountains and Thuringian Mountains. $\bullet$ A - cross section of specimen MB.C.19199 (Bartzsch \& Weyer 1985 Coll.) from the Vogelsberg near Göschitz; × 1.0. • B - cross section of specimen MB.C.19175 from Bredelar; $\times$ 1.0. $\bullet$ C - suture line of specimen MB.C.19194 (Bartzsch \& Weyer 1985 Coll.) from the Vogelsberg near Göschitz, at $11.6 \mathrm{~mm}$ ww, $34.0 \mathrm{~mm}$ wh; $\times 2.0$. -D - suture line of specimen MB.C.4504 (Denckmann Coll.) from Charlottenzug near Bredelar, at $10.1 \mathrm{~mm}$ ww, $36.2 \mathrm{~mm}$ wh; $\times 2.0$. $\bullet$ E - suture line of specimen MB.C.19183 (Schultz 1967 Coll.) from the Braunsberg near Tegau, at $128.5 \mathrm{~mm} \mathrm{dm,} 26.5 \mathrm{~mm}$ ww, 67.5 mm wh; $\times 1.5$. $\bullet$ F-I - ontogenetic development of the conch width index (ww/dm), umbilical width index (uw/dm), whorl width index (ww/wh), and whorl expansion rate (WER) of all available specimens.

material; it is a well-preserved fragment of a specimen that had a phragmocone diameter of at least $25 \mathrm{~mm}$.

The ontogeny of the suture line (Fig. 10B-H) is characterised by a rather simple stage at $1.3 \mathrm{~mm}$ whorl height (specimen MB.C.22004.4; appr. $2 \mathrm{~mm}$ in dm), where the external lobe is still trifid with a median saddle reaching almost half of the E lobe depth. On the flank follows a wide triangular lateral saddle with a narrowly rounded top, a V-shaped lateral lobe, and a smaller umbilical lobe on the umbilical seam (Fig. 10B). A further subdivided $\mathrm{E}$ lobe can be seen at $2.5 \mathrm{~mm}$ whorl height (specimen MB.C.22003.2; Fig. 10C); the $\mathrm{U}$ lobe has already migrated towards the flank.
During later ontogeny, the number of flank lobes increases from four at $7.5 \mathrm{~mm}$ conch diameter (specimen MB.C.22004.4; Fig. 10D) to ten at $11.3 \mathrm{~mm}$ whorl height (specimen MB.C.22003.1; Fig. 10H), which correlates with a conch diameter of $20 \mathrm{~mm}$. In this stage, which represents the largest specimen in our collection, the ventral lobe and all the secondary external lobes are deep and lanceolate with almost parallel flanks. Particularly the lobes $E_{2}, E_{3}$, and $E_{4}$ are very narrow, being more than twice as deep as wide. The two saddles between the L lobe and the $\mathrm{E}_{2}$ lobe are tectiform at their top.

The largest specimen MB.C.22002 (Ebbighausen Coll.; 

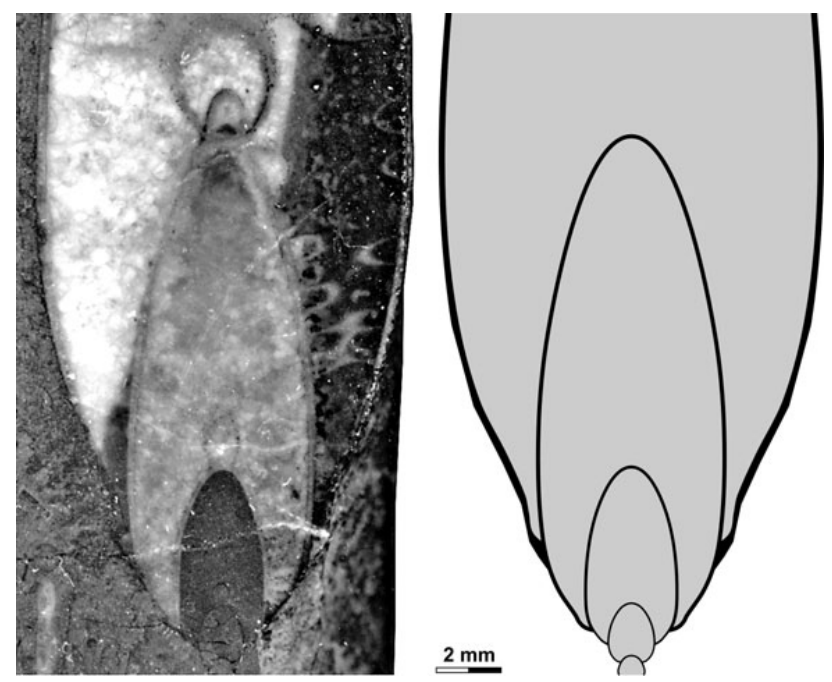

Figure 9. The umbilical region in Beloceras sagittarium (Sandberger \& Sandberger, 1851), shown in the sectioned specimen MB.C.19175, polished surface and digitized cross section; $\times 4.0$.

Fig. 10I) is preserved as a dolomitic steinkern fragment. It belongs to a specimen in which the phragmocone had a diameter of at least $100 \mathrm{~mm}$. In this stage, seven secondary prongs of the external lobe can be counted, the first six of them being lanceolate and the $7^{\text {th }}$ very small and V-shaped. Four saddles between the lateral lobe and the $\mathrm{E}_{8}$ lobe are tectiform at their top.

Remarks. - Material belonging to this species has often been described under the species names multilobatum or sagittarium. Schindewolf (1940, p. 492) noticed the preoccupation of the species name 'Ammonites multilobatus Beyrich, 1837' by 'Ammonites multilobatus Bronn, 1832'; he suggested that 'Goniatites sagittarius Sandberger \& Sandberger, 1851' is a junior synonym of 'Goniatites tenuistriatus d'Archiac \& de Verneuil, 1842'. Schindewolf did not cast any doubt that the specimens figured by d'Archiac $\&$ de Verneuil (1842, pl. 26, fig. 7, 8) represent the same species as 'Goniatites sagittarius Sandberger \& Sandberger, 1851'. Several subsequent authors accepted this concept (e.g. Korn \& Klug 2002), but in this article, we separate the two species on the basis of differences in conch shape and suture line.

Comparisons. - Beloceras tenuistriatum (d'Archiac \& de Verneuil, 1842) is a similar species but possesses a wider umbilicus. While the uw/dm ratio in $B$. sagittarium has a stable value at 0.10 in growth stages larger than $30 \mathrm{~mm}$ in diameter, it is about 0.15 or higher in B. tenuistriatum.

B. sagittarium in Bogoslovsky (1969) = 'Mesobeloceras bogoslovskyi Yatskov, 1990' usually has a wider umbilicus $(\mathrm{uw} / \mathrm{dm}=0.16)$, but there also exist narrowly umbilicate specimens. This has to be solved on the basis of

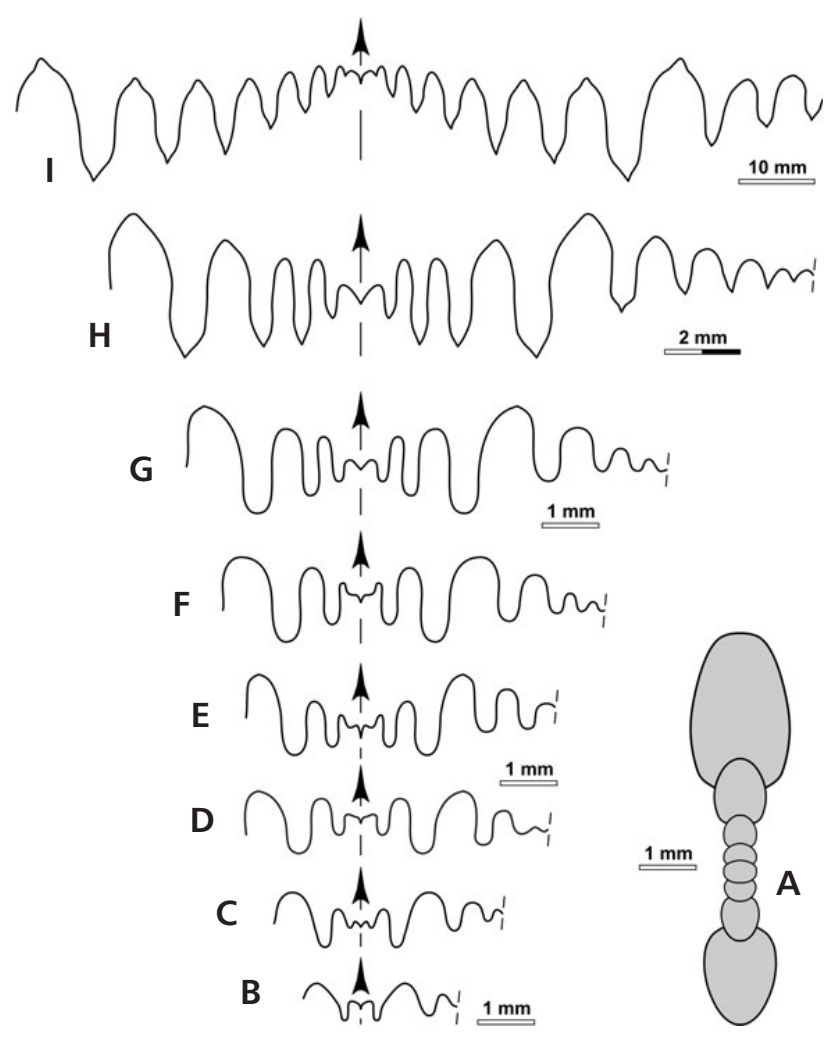

Figure 10. Beloceras sagittarium (Sandberger \& Sandberger, 1851) from Büdesheim. • A - cross section of specimen MB.C.22003.3; × 5.7. - B - suture line of specimen MB.C.22004.4, at $0.9 \mathrm{~mm} w w, 1.3 \mathrm{~mm}$ wh; $\times 5.7$. $\bullet$ - suture line of specimen MB.C. 22003.2 , at $1.7 \mathrm{~mm} \mathrm{ww}, 2.5 \mathrm{~mm}$ wh; $\times$ 5.7. $・ D-$ suture line of specimen MB.C.22004.4, at $7.6 \mathrm{~mm} \mathrm{dm}$, $1.6 \mathrm{~mm}$ ww, $2.7 \mathrm{~mm} \mathrm{wh} ; \times 5.7$. $-\mathrm{E}$ - suture line of specimen MB.C. 22004.1 , at $8.0 \mathrm{~mm} \mathrm{dm}, 1.7 \mathrm{~mm}$ ww, $3.2 \mathrm{~mm}$ wh; $\times 5.7$. $\bullet \mathrm{F}$ - suture line of specimen MB.C.22003.2, at $9.4 \mathrm{~mm} \mathrm{dm}, 2.4 \mathrm{~mm} w w, 4.4 \mathrm{~mm}$ wh; $\times$ 5.7. $\bullet \mathrm{G}-$ suture line of specimen MB.C.22003.4, at $10.5 \mathrm{~mm} \mathrm{dm}$, $2.5 \mathrm{~mm} \mathrm{ww}, 4.5 \mathrm{~mm} \mathrm{wh} ; \times 5.7$. $\mathrm{H}$ - suture line of specimen MB.C.22003.1, at $4.6 \mathrm{~mm} \mathrm{ww}, 11.3 \mathrm{~mm} \mathrm{wh} \times 3.8$. $\bullet$ I - suture line of specimen MB.C.22002 (Ebbighausen Coll.), at $25 \mathrm{~mm}$ ww, ca $70 \mathrm{~mm}$ wh; $\times 0.75$.

the original material. At $28.7 \mathrm{~mm}$ whorl height (corresponding to a conch diameter of about $55 \mathrm{~mm}$ ), five of the saddles on the flank have a tectiform top unlike $B$. $s a$ gittarium, in which only two or three of these saddles are tectiform.

B. stenumbilicatum Bogoslovsky, 1958 has a very similar conch shape, but differs in the shallower, less lanceolate secondary prongs of the external lobe.

B. sagittarium in Glenister $(1958)=$ 'Mesobeloceras glenisteri Yatskov, 1990' has a wider umbilicus (uw/dm = 0.19 at $125 \mathrm{~mm} \mathrm{dm}$, uw/dm $=0.15$ at $85 \mathrm{~mm} \mathrm{dm}$, uw $/ \mathrm{dm}=$ 0.15 at $35 \mathrm{~mm} \mathrm{dm}$ ) than $B$. sagittarium. The largest specimen figured by Glenister (1958, pl. 13, fig. 4) shows that the umbilicus is being widened rapidly in the adult stage, visible in the callus preserved on the penultimate volution.

B. sagittarium in Schulz $(1967)=$ 'Ceratobeloceras schulzi House \& Kirchgasser, 1985’ has a very similar 
conch shape with a very narrow umbilicus (uw/dm = less than 0.10 at $70 \mathrm{~mm}$ conch diameter). The peculiar anomaly of the suture line, i.e. the secondary serration of the L lobe and $\mathrm{U}_{2}$ lobe led House \& Kirchgasser (1985) to introduce the new genus Ceratobeloceras. However, as Schulz (1967) already demonstrated, the serration of the lobes is usually asymmetric on both sides of the conch and many specimens of his collection do not display any secondary serration. It is therefore questionable if a valid character is represented here, and if the material in fact belongs to a separate species or genus. Other reasons for the serration have to be discussed, e.g. pathology. One has to keep in mind that the $\mathrm{L}$ lobe and the $\mathrm{U}_{2}$ lobe are lanceolate, possessing three tie points according to Seilacher (1975). The trifid serration of the lobes is possibly caused by the inactivity of the middle of these three tie points. Yatskov (1990) treated Ceratobeloceras as a subgenus of Beloceras and accepted the separation of the species. He introduced the new species name 'Beloceras (Beloceras) gallicum Yatskov, 1990' for the specimens with non-serrated suture lines and 'Beloceras (Ceratobeloceras) schulzi House \& Kirchgasser, 1985 ' for those with serration.

\section{Beloceras tenuistriatum (d'Archiac \& de Verneuil, 1842)}

Figures 5A, B, E, F, 11, 12

* 1842 Goniatites tenuistriatus d'Archiac \& de Verneuil, p. 343 , pl. 26, fig. 7,8 .

1851 Goniatites sagittarius Sandberger \& Sandberger, pl. 4 , fig. $3 \mathrm{c}-\mathrm{e}$.

1940 Beloceras tenuistriatum. - Schindewolf, p. 492, pl. 1, fig. 17.

non 1959 Beloceras tenuistriatum var. ?. - Petter, p. 184, pl. 10, fig. 1, text-fig. 44A. [= Beloceras petterae Yatskov, 1990]

non 1999 Beloceras tenuistriatum. - Belka et al., p. 10 [= Beloceras petterae Yatskov, 1990]

non 2002 Beloceras tenuistriatum. - Korn \& Klug, text-fig. 112. [= Beloceras glenisteri (Yatskov, 1990)]

non 2002 Beloceras tenuistriatum. - Korn \& Klug, text-fig. 114, 115B, E. [= Beloceras bogoslovskyi (Yatskov, 1990)]

Type material. - The type material of the species from Oberscheld has probably never been studied after the original description. It is presently not known where it is stored.

Material. - Specimens from the eastern margin of the Rhenish Mountains are available for study: 21 specimens (15-71 mm in conch diameter) come from the Martenberg near Adorf, one specimen $75 \mathrm{~mm}$ in $\mathrm{dm}$ is labelled 'Bredelar' and is probably from the Charlottenzug Mine, and eleven specimens with conches measuring up to $100 \mathrm{~mm}$ in diameter come from the vicinity of Oberscheld.

Diagnosis. - Species of Beloceras with subinvolute conch (uw/dm $=0.15$ in stages larger than $50 \mathrm{~mm} \mathrm{dm}$ ). Suture line with six or seven secondary prongs of the external lobe, a V-shaped lateral lobe, and six umbilical lobes on the flanks at $50 \mathrm{~mm}$ conch diameter; formula of the ventral suture line in this growth stage $\left(\mathrm{E}_{2} \mathrm{E}_{3} \mathrm{E}_{4} \mathrm{E}_{5} \mathrm{E}_{6} \mathrm{E}_{7} \mathrm{E}_{1} \mathrm{E}_{7} \mathrm{E}_{6} \mathrm{E}_{5} \mathrm{E}_{4} \mathrm{E}_{3} \mathrm{E}_{2}\right)$ $\mathrm{L} \mathrm{U}_{2} \mathrm{U}_{4} \mathrm{U}_{6} \mathrm{U}_{8} \mathrm{U}_{10} \mathrm{U}_{12}$. All prongs of the external lobe are lanceolate, the $\mathrm{E}_{5}$ and $\mathrm{E}_{6}$ lobes are very narrow and deep; three or four of the larger saddles (between the L lobe and the $\mathrm{E}_{4}$ lobe) are weakly tectiform. The adult suture is with an increasing number of very shallow $U$ lobes.

Description. - The well-preserved specimen MB.C.4506 (71 mm in dm; Müller Coll.; Fig. 11B) from the Martenberg near Adorf is extremely discoidal with a narrow umbilicus $(\mathrm{ww} / \mathrm{dm}=0.16 ; \mathrm{uw} / \mathrm{dm}=0.15)$ and an extremely high aperture (WER $=2.61$ ). It shows a narrowly rounded venter and the very shallow umbilical margin, which separates the flat flank from the strongly oblique umbilical wall. The shell surface is almost smooth.

Specimen MB.C.22006 (Reinke 1882 Coll.; Fig. 11A) with a conch diameter of $75 \mathrm{~mm}$ from 'Bredelar' (probably from the Charlottenzug Mine according to the lithology) is, in its conch proportions, similar to the preceding specimen ( $\mathrm{ww} / \mathrm{dm}=0.18$; uw/dm $=0.16$; WER $=2.46$ ). The umbilical area is well-preserved; it shows a pronounced umbilical seam, a faint rim on the inner umbilical wall, followed by a shallow spiral groove, and a very shallow umbilical wall with a broadly rounded umbilical margin. There are well-preserved shell remains on the specimen, which show delicate growth lines with a shallow dorsal sinus and a low ventrolateral projection. The growth lines are much coarser on the outer flank and form a very deep and narrow ventral sinus.

Specimen MB.C.22007 (Denckmann 1893 Coll.; Fig. 11C) from the Martenberg is a well-preserved specimen measuring $50 \mathrm{~mm}$ in diameter. It is also extremely discoidal and subinvolute $(\mathrm{ww} / \mathrm{dm}=0.20 ; \mathrm{uw} / \mathrm{dm}=0.15)$ with a comparatively low aperture (WER $=2.15)$. An umbilical rim and an accompanying spiral groove are developing on the last volution, where the umbilical wall becomes much shallower than in the inner whorls. The steinkern of the body chamber shows the Ritzstreifung, which is composed of delicate radial lines, which extend in a protracted direction across the flank.

Comparisons. - B. sagittarium is similar but possesses a narrower umbilicus in growth stages larger than $50 \mathrm{~mm}$ (uw/dm $=0.15$ in B. tenuistriatum and 0.10 in B. sagittarium). While in $B$. sagittarium the umbilicus is continuously closing, it begins to open in B. tenuistriatum at a 

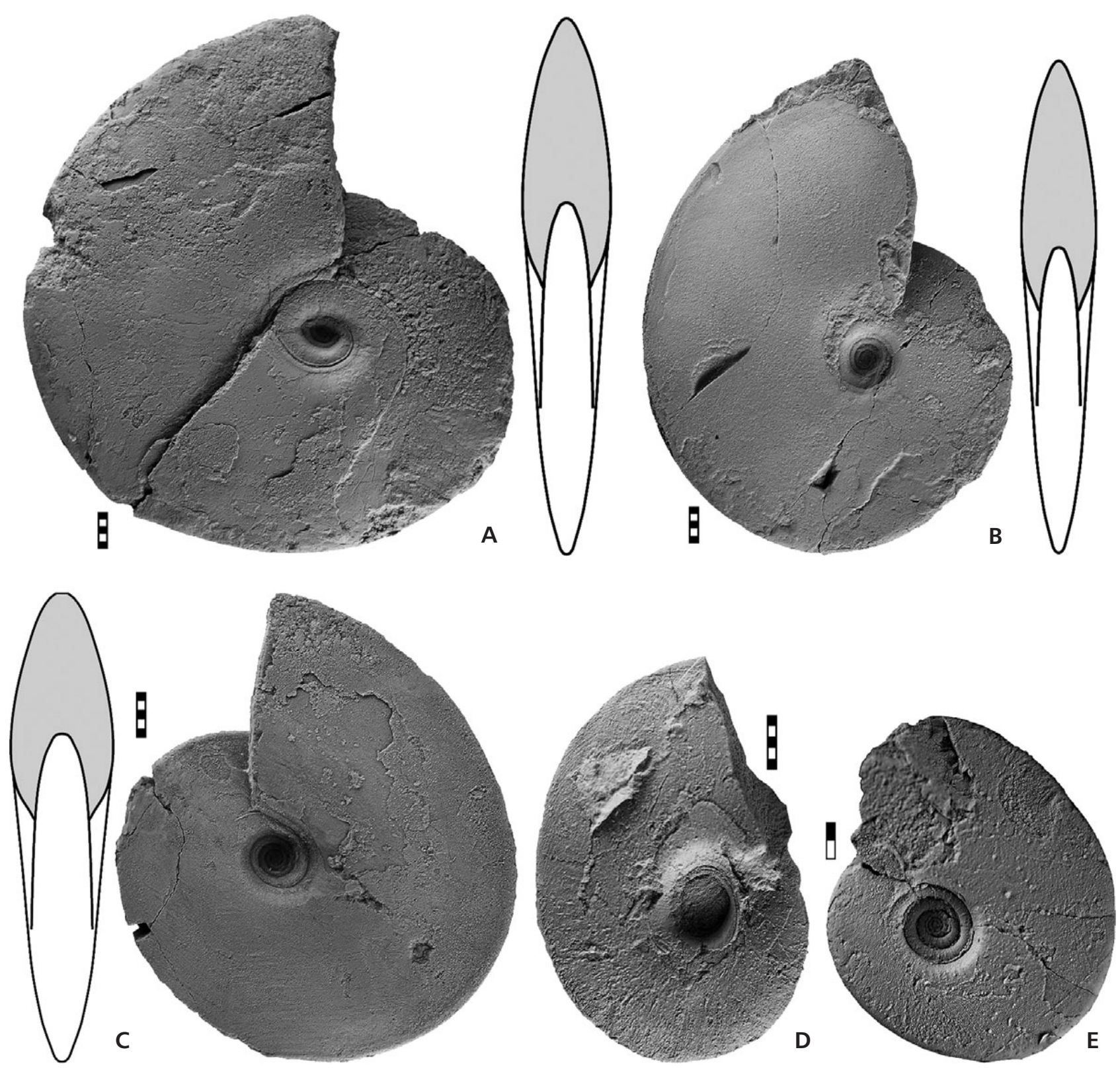

Figure 11. Beloceras tenuistriatum (d'Archiac \& de Verneuil, 1842) from the Rhenish Mountains. • A - specimen MB.C.22006 (Reinke 1882 Coll.) from Bredelar; × 1.0. • B - specimen MB.C.4506 (Müller Coll.) from the Martenberg near Adorf; × 1.0. $\bullet$ C - specimen MB.C.22007 (Denckmann 1893 Coll.) from the Martenberg near Bredelar; $\times$ 1.25. $\bullet$ D - specimen MB.C.22011 (Denckmann 1902 Coll.) from the Martenberg near Bredelar; $\times 1.5$. -E - specimen MB.C.4057.4 (Müller Coll.) from the Martenberg near Bredelar; $\times 2.5$.

conch diameter of about $50 \mathrm{~mm}$. This is already visible in the figure of d'Archiac \& de Verneuil (1842, pl. 26, fig. 7), which is refigured here (Fig. 5A). The umbilical rim is more pronounced in $B$. tenuistriatum.

B. webbelense has similar conch dimensions and ratios. The two species differ in the suture line, which is more complex in B. tenuistriatum (six secondary external lobes; Fig. 12B, C) than in B. webbelense (four secondary external lobes). Additionally, $B$. webbelense possesses a more conspicuous umbilical rim.
B. glenisteri, from the Canning Basin of Australia, is very similar. The suture figure in Glenister (1958, text-fig. 15d) is from a specimen measuring $50 \mathrm{~mm}$ in diameter, thus similar in size to specimen MB.C.22013.1. Both show six secondary prongs of the external lobe, and the difference between them is only in the shape of the lobes and saddle, with more lanceolate lobes and tectiform saddles in B. glenisteri. An additional difference between the two species lies in the conch ontogeny as B. glenisteri is more widely umbilicate in the adult stage. 


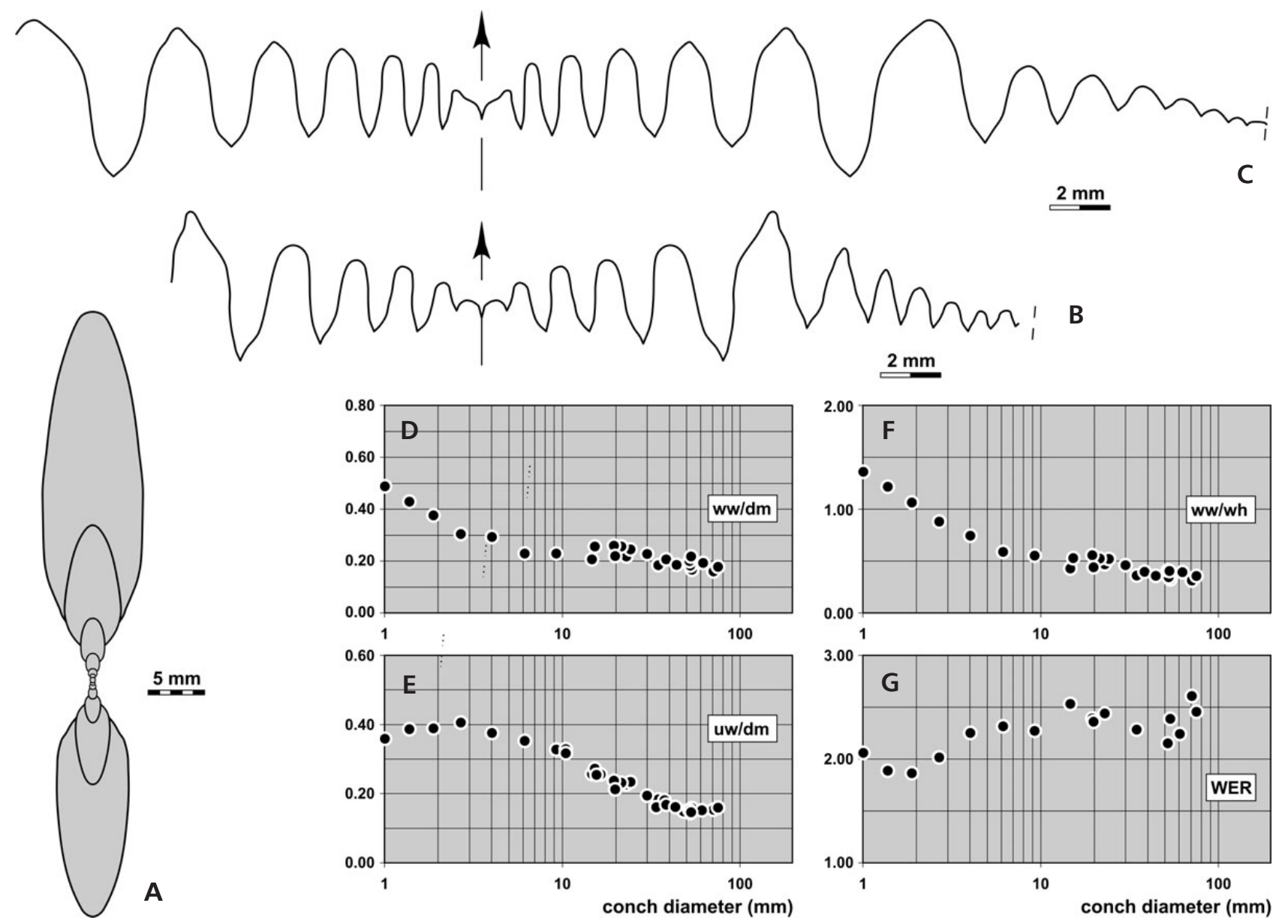

Figure 12. Beloceras tenuistriatum (d'Archiac \& de Verneuil, 1842) from the Rhenish Mountains. • A - cross section of specimen MB.C.22010 (Paeckelmann 1928 Coll.) from the Martenberg near Adorf; $\times$ 1.5. • B - suture line of specimen MB.C.22007 (Denckmann 1893 Coll.) from the Martenberg near Adorf, at $37.0 \mathrm{~mm}$ dm, $9.0 \mathrm{~mm}$ ww, $19.0 \mathrm{~mm}$ wh; $\times 4.0$. $\bullet$ C - suture line of specimen MB.C.22013.1 from the Martenberg near Adorf, at $27.0 \mathrm{~mm}$ wh; $\times 4.0 . \bullet \mathrm{D}-\mathrm{G}-$ ontogenetic development of the conch width index (ww/dm), umbilical width index (uw/dm), whorl width index (ww/wh), and whorl expansion rate (WER) of all available specimens.

\section{Beloceras webbelense sp. nov.}

Figures 13, 14

1882 Goniatites multilobatus. - Holzapfel, p. 237, pl. 45, figs 2-6.

1913 Beloceras multilobatum. - Wedekind, p. 48, textfig. $5 \mathrm{a} 2$.

1918 Beloceras multilobatum. - Wedekind, p. 129, textfig. $38 \mathrm{a} 2$, pl. 21, fig. 13 .

Derivation of name. - After the Webbel Mine near Adorf.

Holotype. - Specimen MB.C.22025 (Paeckelmann 1920 Coll.); illustrated here in Fig. 13A.

Type locality and horizon. - Martenberg near Adorf; 'Webeler Kalk' (red Frasnian cephalopod limestones).
Material. - Sixteen specimens from the vicinity of Adorf are available for study.

Diagnosis. - Species of Beloceras with subinvolute conch (uw/dm $=0.17$ in stages larger than $50 \mathrm{~mm}$ in $\mathrm{dm}$ ). Two distinct spiral rims on the umbilical wall. Suture line with four secondary prongs of the external lobe, a V-shaped lateral lobe, and four umbilical lobes on the flanks at $45 \mathrm{~mm}$ conch diameter; formula of the ventral suture line in this growth stage $\left.\left(E_{2} E_{3} E_{4} E_{5} E_{1} E_{5} E_{4} E_{3} E_{2}\right) L U_{2} U_{4} U_{6} U_{8}\right)$. Prongs of the external lobe are narrowly $\mathrm{V}$-shaped to lanceolate; the saddle between the $\mathrm{L}$ lobe and the $\mathrm{E}_{2}$ lobe is weakly tectiform.

Description. - Holotype MB.C.22025 (Paeckelmann 1920 Coll.) is an incomplete but well-preserved specimen, measuring $89 \mathrm{~mm}$ in diameter, from the 'Webeler Kalk' of the Martenberg near Adorf (Fig. 13A). It is preserved with 
Table 5. Conch ontogeny (Fig. 11, 12) of Beloceras tenuistriatum (d'Archiac \& de Verneuil, 1842).

\begin{tabular}{|c|c|c|c|}
\hline $\mathrm{dm}$ & conch shape & whorl cross section shape & aperture \\
\hline $1.5 \mathrm{~mm}$ & $\begin{array}{l}\text { thinly discoidal; subevolute } \\
\text { (ww/dm } \sim 0.45 ; \text { uw/dm } \sim 0.40 \text { ) }\end{array}$ & weakly depressed; moderately embracing (ww/wh 1.25; IZR 0.22) & moderate $($ WER 1.95) \\
\hline $4 \mathrm{~mm}$ & $\begin{array}{l}\text { extremely discoidal; subevolute } \\
\text { (ww/dm } \sim 0.28 ; \text { uw } / \mathrm{dm} \sim 0.38 \text { ) }\end{array}$ & weakly compressed; moderately embracing (ww/wh $\sim 0.75 ; \mathrm{IZR} \sim 0.15$ ) & high (WER 2.25) \\
\hline $8 \mathrm{~mm}$ & $\begin{array}{l}\text { extremely discoidal; subevolute } \\
\text { (ww/dm } \sim 0.23 ; \text { uw/dm } \sim 0.35 \text { ) }\end{array}$ & weakly compressed; moderately embracing $($ ww/wh $\sim 0.55 ;$ IZR $~ 0.18)$ & very high $($ WER 2.30) \\
\hline $18 \mathrm{~mm}$ & $\begin{array}{l}\text { extremely discoidal; subinvolute } \\
\text { (ww/dm } \sim 0.25 ; \text { uw/dm } \sim 0.22 \text { ) }\end{array}$ & strongly compressed; strongly embracing (ww/wh 0.45; IZR 0.30) & very high $($ WER 2.40) \\
\hline $50 \mathrm{~mm}$ & $\begin{array}{l}\text { extremely discoidal; subinvolute } \\
\text { (ww/dm } \sim 0.20 ; \text { uw/dm } \sim 0.15 \text { ) }\end{array}$ & strongly compressed; strongly embracing (ww/wh 0.40; IZR 0.32) & very high $($ WER 2.30) \\
\hline $75 \mathrm{~mm}$ & $\begin{array}{l}\text { extremely discoidal; subinvolute } \\
\text { (ww/dm } \sim 0.18 ; \mathrm{uw} / \mathrm{dm} \sim 0.16 \text { ) }\end{array}$ & strongly compressed; moderately embracing $(\mathrm{ww} / \mathrm{wh} \sim 0.35$; IZR $\sim 0.27$ ) & $\begin{array}{l}\text { very to extremely high } \\
\text { (WER } \sim 2.4-2.65)\end{array}$ \\
\hline
\end{tabular}

Table 6. Conch dimensions (in mm) and proportions for reference specimens of Beloceras tenuistriatum (d'Archiac \& de Verneuil, 1842).

\begin{tabular}{|c|c|c|c|c|c|c|c|c|c|c|}
\hline & $\mathrm{dm}$ & ww & Wh & Uw & $\mathrm{ah}$ & ww/dm & ww/wh & uw/dm & WER & IZR \\
\hline MB.C.22006 & 75.1 & 13.3 & 37.5 & 12.0 & 27.2 & 0.18 & 0.35 & 0.16 & 2.46 & 0.27 \\
\hline MB.C.4506 & 70.8 & 11.3 & 36.3 & 10.9 & 27.0 & 0.16 & 0.31 & 0.15 & 2.61 & 0.26 \\
\hline MB.C.22007 & 51.8 & 10.3 & 25.4 & 7.9 & 16.5 & 0.20 & 0.41 & 0.15 & 2.15 & 0.35 \\
\hline MB.C.22011 & 37.6 & 9.7 & 19.0 & 6.8 & - & 0.26 & 0.51 & 0.18 & - & - \\
\hline MB.C.4507.4 & 19.5 & 5.1 & 9.1 & 4.6 & 6.9 & 0.26 & 0.56 & 0.24 & 2.39 & 0.24 \\
\hline \multirow[t]{11}{*}{ MB.C. 22010} & 53.6 & 8.9 & 27.5 & 8.5 & 18.9 & 0.17 & 0.32 & 0.16 & 2.39 & 0.31 \\
\hline & 34.7 & 6.4 & 17.7 & 6.4 & 11.7 & 0.18 & 0.36 & 0.18 & 2.28 & 0.34 \\
\hline & 23.0 & 5.0 & 10.7 & 5.2 & 8.3 & 0.22 & 0.47 & 0.23 & 2.44 & 0.23 \\
\hline & 14.7 & 3.0 & 7.1 & 3.8 & 5.5 & 0.21 & 0.43 & 0.26 & 2.53 & 0.23 \\
\hline & 9.24 & 2.12 & 3.84 & 3.02 & 3.11 & 0.23 & 0.55 & 0.33 & 2.27 & 0.19 \\
\hline & 6.13 & 1.40 & 2.38 & 2.17 & 2.10 & 0.23 & 0.59 & 0.35 & 2.32 & 0.12 \\
\hline & 4.03 & 1.18 & 1.59 & 1.51 & 1.34 & 0.29 & 0.75 & 0.38 & 2.25 & 0.15 \\
\hline & 2.68 & 0.82 & 0.93 & 1.09 & 0.79 & 0.30 & 0.88 & 0.41 & 2.02 & 0.15 \\
\hline & 1.89 & 0.71 & 0.67 & 0.73 & 0.51 & 0.38 & 1.06 & 0.39 & 1.87 & 0.24 \\
\hline & 1.38 & 0.59 & 0.49 & 0.53 & 0.38 & 0.43 & 1.22 & 0.39 & 1.89 & 0.23 \\
\hline & 1.01 & 0.49 & 0.36 & 0.36 & 0.31 & 0.49 & 1.36 & 0.36 & 2.06 & 0.16 \\
\hline
\end{tabular}

parts of the body chamber, and the phragmocone is filled with sparry calcite; suture lines are therefore not preserved. The conch is extremely discoidal $(\mathrm{ww} / \mathrm{dm}=0.16)$ and subinvolute (uw/dm $=0.17$ ) with a very high aperture (WER = 2.43). The conch is thickest at some distance from the umbilicus, and the umbilical wall is very shallow with the last whorl connecting smoothly with the preceding volution. A rim marks the umbilical seam, and the umbilical wall possesses a shallow groove. The flanks converge slowly towards the narrowly rounded venter. The shell surface is almost smooth but possesses extremely fine growth lines, which form a low ventrolateral projection. On the outer flank, the growth lines are more pronounced and turn back to form a very narrow and very deep ventral sinus. They are strengthened on the venter and look like chevron-shaped delicate riblets.
The smaller paratype MB.C.22029 (Paeckelmann 1920 Coll.; Fig. 13B) from the Webbel Mine near Adorf has similar conch proportions at a diameter of $72 \mathrm{~mm}(\mathrm{ww} / \mathrm{dm}=$ 0.17 ; uw/dm =0.17; WER = 2.32). It also shows a rim near the umbilical seam and a shallow groove on the umbilical wall. The shell surface is not as well preserved as in the holotype, but also displays the strengthening of the growth lines on the outer flank and the venter. The wrinkle layer is well preserved in the dorsal whorl where parts of the body chamber are removed.

The juvenile paratype MB.C.22030 (Denckmann Coll.; Fig. 13B) has a conch diameter of $27 \mathrm{~mm}$ and is extremely discoidal and subinvolute $(\mathrm{ww} / \mathrm{dm}=0.19 ; \mathrm{uw} / \mathrm{dm}=0.20)$ with a high aperture (WER $=2.16)$. The conch is widest near the umbilicus, and the umbilical wall does not possess a rim and groove as with the larger specimens. The shell surface is smooth on the inner and middle flank, but the 

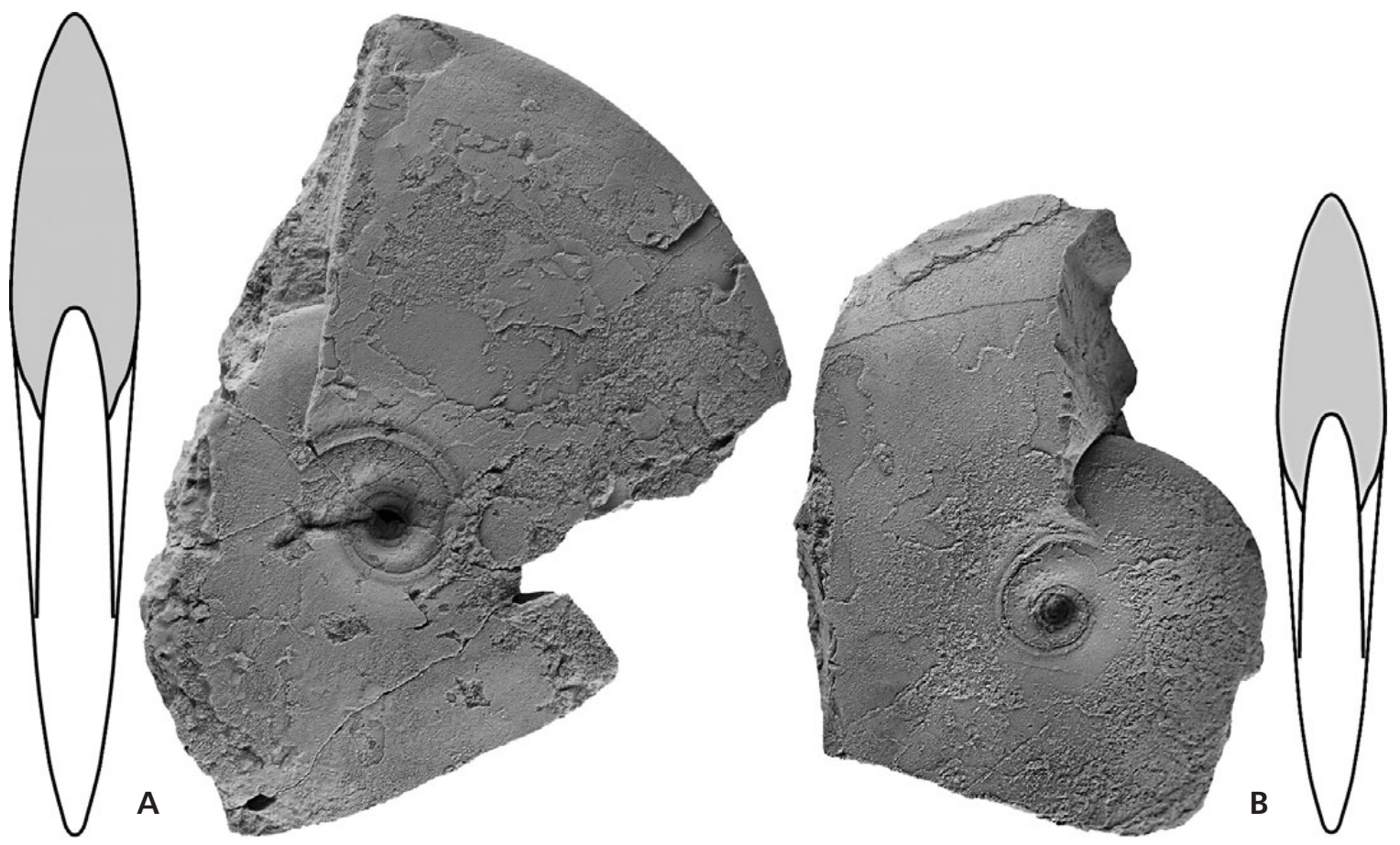

Figure 13. Beloceras webbelense sp. nov. from the Rhenish Mountains; all $\times 1.0$. A - holotype MB.C.22025 (Paeckelmann 1920 Coll.) from the Martenberg near Adorf. • B - paratype MB.C.22029 (Paeckelmann 1920 Coll.) from the Webbel Mine near Adorf.
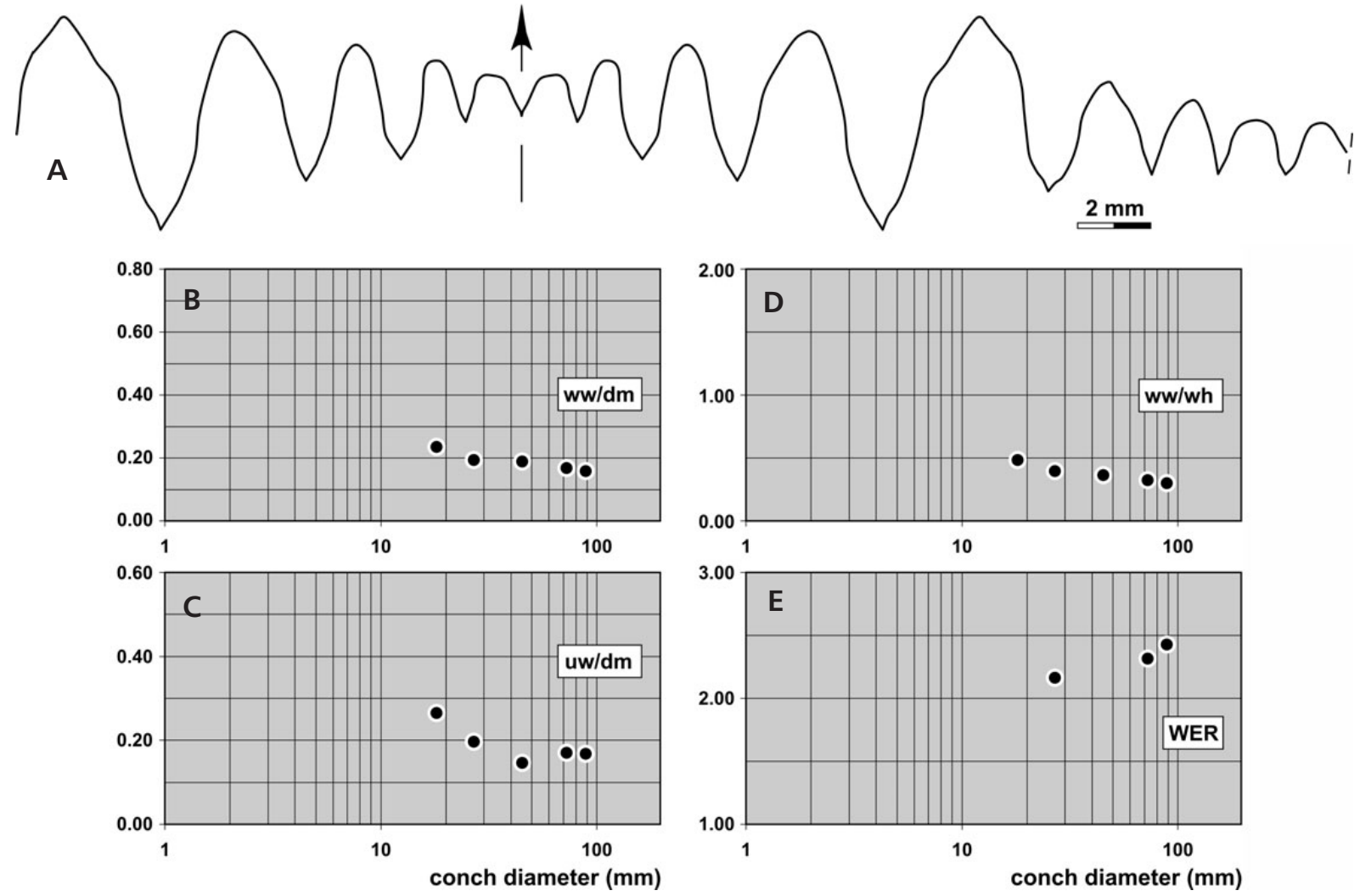

Figure 14. Beloceras webbelense sp. nov. from the Rhenish Mountains. • A - suture line of paratype MB.C.22026 (Paeckelmann 1920 Coll.) from the Martenberg near Adorf, at $8.4 \mathrm{~mm} \mathrm{ww}, 23.6 \mathrm{~mm}$ wh; $\times 4.0$. $\bullet$ B-E - ontogenetic development of the conch width index (ww/dm), umbilical width index (uw/dm), whorl width index (ww/wh), and whorl expansion rate (WER) of all available specimens. 
Table 7. Conch ontogeny (Fig. 13, 14) of Beloceras webbelense sp. nov.

\begin{tabular}{llll}
\hline $\mathrm{dm}$ & conch shape & whorl cross section shape & aperture \\
\hline $27 \mathrm{~mm}$ & $\begin{array}{l}\text { extremely discoidal; subinvolute } \\
(\mathrm{ww} / \mathrm{dm} \sim 0.19 ; \mathrm{uw} / \mathrm{dm} \sim 0.20)\end{array}$ & strongly compressed; strongly embracing (ww/wh $\sim 0.40 ;$ IZR $\sim 0.35)$ & high $($ WER $\sim 2.15)$ \\
$90 \mathrm{~mm}$ & $\begin{array}{l}\text { extremely discoidal; subinvolute } \\
(\mathrm{ww} / \mathrm{dm} \sim 0.16 ; \mathrm{uw} / \mathrm{dm} \sim 0.16)\end{array}$ & strongly compressed; strongly embracing $(\mathrm{ww} / \mathrm{wh} \sim 0.30 ;$ IZR $\sim 0.32)$ & very high $(\mathrm{WER} \sim 2.45)$ \\
\hline
\end{tabular}

Table 8. Conch dimensions (in $\mathrm{mm}$ ) and proportions for reference specimens of Beloceras webbelense sp. nov.

\begin{tabular}{lcccccccccccc}
\hline & $\mathrm{dm}$ & ww & wh & uw & ah & ww/dm & Ww/wh & uw/dm & WER & IZR \\
\hline MB.C.22025 & 88.8 & 14.0 & 46.8 & 14.9 & 31.8 & 0.16 & 0.30 & 0.17 & 2.43 & 0.32 \\
MB.C.22029 & 72.3 & 12.2 & 37.8 & 12.3 & 24.8 & 0.17 & 0.32 & 0.17 & 2.32 & 0.34 \\
MB.C.22030 & 26.9 & 5.2 & 13.2 & 5.3 & 8.6 & 0.19 & 0.40 & 0.20 & 2.16 & 0.35 \\
\hline
\end{tabular}

growth lines are significantly strengthened on the outer flank, where they turn back for a very deep and narrow ventral sinus on the narrow, nearly flat venter.

Paratype MB.C.22026 (Paeckelmann 1920 Coll.; Fig. 14A) shows the suture line at a whorl height of about $24 \mathrm{~mm}$ (corresponding to a conch diameter of about $45 \mathrm{~mm}$ ). At this stage, it has four secondary prongs of the external lobe; they are all narrowly $\mathrm{V}$-shaped with a tendency towards a lanceolate shape towards the venter. The saddle between the $\mathrm{E}_{1}$ lobe and the $\mathrm{L}$ lobe is tectiform with flanks slightly incurved in the upper part. The lateral lobe is lanceolate with a mammiform base. Three umbilical lobes are present on the flank; they are $\mathrm{V}$-shaped and almost symmetrical.

Comparisons. - B. webbelense resembles B. tenuistriatum in conch shape but differs in the less advanced suture line and the much more pronounced spiral umbilical rims. At a conch diameter of about $45 \mathrm{~mm}, B$. webbelense possesses four secondary prongs on the external lobe in contrast to B. tenuistriatum, which has already six of such additional lobes. The umbilical rim is more pronounced in $B$. webbelense.

B. petterae from the Anti-Atlas is similar with respect to conch shape and number of sutural elements, but in this species, the secondary prongs of the external lobe and the saddles between them form a rather regular zigzag pattern, while the secondary prongs in $B$. webbelense are more lanceolate with narrowly rounded saddles between them.

\section{Beloceras petterae Yatskov, 1990}

Figures 15, 16

1959 Beloceras tenuistriatum var. ?. - Petter, p. 184, pl. 10, fig. 1, text-fig. 44A.

* 1990 Beloceras (Beloceras) petterae Yatskov, p. 48.

1999 Beloceras tenuistriatum - Belka et al., p. 10.

Holotype. - The specimen figured by Petter (1959, pl. 10, fig. 1).
Type locality and horizon. - Ride de l'Adrar (Tafilalt, Anti-Atlas); Frasnian.

Material. - Thirty-seven specimens up to $114 \mathrm{~mm}$ conch diameter from the area around Erfoud in the eastern Anti-Atlas of Morocco.

Diagnosis. - Species of Beloceras with subinvolute conch (uw/dm $=0.18-0.22$ in stages larger than $50 \mathrm{~mm} \mathrm{dm}$ ). Suture line with four secondary prongs of the external lobe, a $\mathrm{V}$-shaped lateral lobe, and four umbilical lobes on the flanks at $80 \mathrm{~mm}$ conch diameter; formula of the ventral suture line in this growth stage $\left(\mathrm{E}_{2} \mathrm{E}_{3} \mathrm{E}_{4} \mathrm{E}_{5} \mathrm{E}_{1} \mathrm{E}_{5} \mathrm{E}_{4} \mathrm{E}_{3} \mathrm{E}_{2}\right) \mathrm{L}$ $\mathrm{U}_{2} \mathrm{U}_{4} \mathrm{U}_{6} \mathrm{U}_{8} \mathrm{U}_{10} \mathrm{U}_{12}$ ). The prongs of the external lobe are narrowly V-shaped; the saddle between the L lobe and the $\mathrm{E}_{2}$ lobe is tectiform.

Description. - Specimen MB.C.22034 (Bockwinkel Coll.; Fig. 15C) is a fully septate, partly corroded specimen with a conch diameter of $114 \mathrm{~mm}$; it is extremely discoidal $(\mathrm{ww} / \mathrm{dm}=0.15)$ and subinvolute $(\mathrm{uw} / \mathrm{dm}=0.19)$ with a high aperture (WER $=2.24)$. The relatively wide umbilicus is caused by the fact that the shell, which partly overlaps the umbilicus, is missing on parts of the specimen.

Specimen MB.C.22032 (Bockwinkel Coll.; Fig. 15A) is a fully septate, well-preserved individual from Ouidane Chebbi. It possesses the characteristic conch proportions of the species; at $80 \mathrm{~mm}$ in diameter it is extremely discoidal $(\mathrm{ww} / \mathrm{dm}=0.16)$ and subinvolute $(\mathrm{uw} / \mathrm{dm}=0.17)$ with an extremely high aperture (WER $=2.73$ ). The conch is widest at the rounded umbilical margin, which separates the shallow and slightly concave umbilical wall from the slowly converging flanks. The venter is subacute. Parts of the steinkern are covered with shell remains, which appear to be smooth. It can be seen that the shell forms an umbilical thickening that contributes to a closure of the umbilicus.

The two smaller specimens MB.C.22040.1 and MB.C.22040.2 (Wendt Coll.) from Lahmida closely 
Table 9. Conch ontogeny (Fig. 15, 16) of Beloceras petterae Yatskov, 1990.

\begin{tabular}{|c|c|c|c|}
\hline $\mathrm{dm}$ & conch shape & whorl cross section shape & aperture \\
\hline $2 \mathrm{~mm}$ & $\begin{array}{l}\text { extremely discoidal; evolute } \\
(\mathrm{ww} / \mathrm{dm} \sim 0.32 ; \mathrm{uw} / \mathrm{dm}=0.40-0.45)\end{array}$ & $\begin{array}{l}\text { weakly compressed; moderately embracing } \\
(\mathrm{ww} / \mathrm{wh}=0.90-1.05 ; \mathrm{IZR}=0.15-0.18)\end{array}$ & moderate $($ WER $=1.75-2.00)$ \\
\hline $8 \mathrm{~mm}$ & $\begin{array}{l}\text { extremely discoidal; subevolute } \\
(\mathrm{ww} / \mathrm{dm} \sim 0.25 ; \mathrm{uw} / \mathrm{dm}=0.35-0.45)\end{array}$ & $\begin{array}{l}\text { weakly compressed; moderately embracing } \\
\text { (ww/wh } \sim 0.75 ; \text { IZR } \sim 0.15 \text { ) }\end{array}$ & moderate to high $($ WER $=1.90-2.20)$ \\
\hline $18 \mathrm{~mm}$ & $\begin{array}{l}\text { extremely discoidal; subinvolute to subevolute } \\
\text { (ww/dm } \sim 0.25 ; \mathrm{uw} / \mathrm{dm}=0.25-0.32 \text { ) }\end{array}$ & $\begin{array}{l}\text { weakly compressed; moderately embracing } \\
\text { (ww/wh } \sim 0.55 ; \text { IZR } \sim 0.25 \text { ) }\end{array}$ & high (WER 2.20) \\
\hline $50 \mathrm{~mm}$ & $\begin{array}{l}\text { extremely discoidal; subinvolute } \\
(\mathrm{ww} / \mathrm{dm}=0.17-0.20 ; \mathrm{uw} / \mathrm{dm}=0.18-0.22)\end{array}$ & $\begin{array}{l}\text { extremely compressed; strongly embracing } \\
(\mathrm{ww} / \mathrm{wh}=0.30-0.35 ; \mathrm{IZR} \sim 0.30)\end{array}$ & high to extremely high $($ WER $=2.15-2.60)$ \\
\hline $80 \mathrm{~mm}$ & $\begin{array}{l}\text { extremely discoidal; subinvolute } \\
\text { (ww/dm } \sim 0.16 ; \mathrm{uw} / \mathrm{dm} \sim 0.18 \text { ) }\end{array}$ & $\begin{array}{l}\text { extremely compressed; strongly embracing } \\
\text { (ww/wh }=0.30-0.35 ; \mathrm{IZR} \sim 0.30 \text { ) }\end{array}$ & $\begin{array}{l}\text { very high to extremely high } \\
(\mathrm{WER}=2.30-2.75)\end{array}$ \\
\hline
\end{tabular}

Table 10. Conch dimensions (in mm) and proportions for reference specimens of Beloceras petterae Yatskov, 1990.

\begin{tabular}{|c|c|c|c|c|c|c|c|c|c|c|}
\hline & $\mathrm{dm}$ & ww & wh & uw & $\mathrm{ah}$ & ww/dm & ww/wh & $\mathrm{uw} / \mathrm{dm}$ & WER & IZR \\
\hline MB.C.22034 & 113.7 & 16.6 & 55.7 & 21.2 & 37.7 & 0.15 & 0.30 & 0.19 & 2.24 & 0.32 \\
\hline MB.C.22039 & 92.7 & 15.0 & 45.1 & 18.5 & 30.1 & 0.16 & 0.33 & 0.20 & 2.19 & 0.33 \\
\hline MB.C.22032 & 80.7 & 13.3 & 40.2 & 14.1 & 31.9 & 0.16 & 0.33 & 0.17 & 2.73 & 0.21 \\
\hline MB.C.22040.1 & 55.5 & 9.2 & 27.0 & 10.1 & 19.1 & 0.17 & 0.34 & 0.18 & 2.33 & 0.29 \\
\hline MB.C.22040.2 & 50.0 & 9.1 & 22.7 & 10.9 & 16.0 & 0.18 & 0.40 & 0.22 & 2.17 & 0.29 \\
\hline \multirow[t]{11}{*}{ MB.C.22038 } & 92.5 & 14.3 & 41.6 & 18.9 & 28.9 & 0.15 & 0.34 & 0.20 & 2.12 & 0.30 \\
\hline & 63.6 & 10.3 & 32.0 & 12.0 & 23.7 & 0.16 & 0.32 & 0.19 & 2.55 & 0.26 \\
\hline & 39.9 & 7.7 & 19.6 & 7.8 & 14.2 & 0.19 & 0.39 & 0.20 & 2.41 & 0.28 \\
\hline & 25.7 & 5.8 & 12.5 & 6.1 & 9.1 & 0.23 & 0.47 & 0.24 & 2.40 & 0.27 \\
\hline & 16.6 & 4.0 & 7.1 & 5.5 & 5.5 & 0.24 & 0.56 & 0.33 & 2.22 & 0.23 \\
\hline & 11.1 & 2.5 & 4.0 & 4.6 & 3.4 & 0.22 & 0.62 & 0.41 & 2.04 & 0.16 \\
\hline & 7.79 & 1.92 & 2.56 & 3.45 & 2.18 & 0.25 & 0.75 & 0.44 & 1.93 & 0.15 \\
\hline & 5.61 & 1.49 & 1.79 & 2.57 & 1.52 & 0.27 & 0.83 & 0.46 & 1.89 & 0.15 \\
\hline & 4.09 & 1.15 & 1.26 & 1.95 & 1.09 & 0.28 & 0.92 & 0.48 & 1.86 & 0.13 \\
\hline & 3.00 & 0.86 & 0.89 & 1.44 & 0.74 & 0.29 & 0.98 & 0.48 & 1.76 & 0.17 \\
\hline & 2.26 & 0.70 & 0.68 & - & 0.56 & 0.31 & 1.04 & - & 1.76 & 0.18 \\
\hline \multirow[t]{9}{*}{ MB.C. 22046} & 51.8 & 10.4 & 23.7 & 10.9 & 16.6 & 0.20 & 0.44 & 0.21 & 2.16 & 0.30 \\
\hline & 35.2 & 7.5 & 17.2 & 7.3 & 12.7 & 0.21 & 0.44 & 0.21 & 2.46 & 0.26 \\
\hline & 22.5 & 4.9 & 10.7 & 5.0 & 7.6 & 0.22 & 0.46 & 0.22 & 2.29 & 0.29 \\
\hline & 14.9 & 3.5 & 6.8 & 4.0 & 5.1 & 0.24 & 0.52 & 0.27 & 2.31 & 0.25 \\
\hline & 9.77 & 2.38 & 4.04 & 3.26 & 3.31 & 0.24 & 0.59 & 0.33 & 2.28 & 0.18 \\
\hline & 6.46 & 1.68 & 2.47 & 2.49 & 2.03 & 0.26 & 0.68 & 0.38 & 2.13 & 0.18 \\
\hline & 4.43 & 1.16 & 1.51 & 1.89 & 1.28 & 0.26 & 0.77 & 0.43 & 1.98 & 0.15 \\
\hline & 3.15 & 0.87 & 1.04 & 1.38 & 0.89 & 0.28 & 0.84 & 0.44 & 1.95 & 0.14 \\
\hline & 2.26 & 0.67 & 0.74 & 0.93 & 0.64 & 0.30 & 0.91 & 0.41 & 1.95 & 0.13 \\
\hline
\end{tabular}

resemble each other (Fig. 15D, E). With conch diameters measuring 55 and $50 \mathrm{~mm}$ respectively, they are lenticular $(\mathrm{ww} / \mathrm{dm}=0.17,0.18)$ and subinvolute $(\mathrm{uw} / \mathrm{dm}=0.18$, 0.22). The narrower umbilicus in specimen MB.C.22040.1 is due to the preserved shell that causes a stronger overlap of the whorl upon the preceding one. Both of them possess shell remains, which are chiefly smooth except for delicate growth lines. Additionally, specimen MB.C.22040.1 displays a well-preserved wrinkle layer.
The suture line of specimen MB.C.22032 possesses, at $80 \mathrm{~mm} \mathrm{dm}$, five secondary prongs of the external lobe (Fig. 16D). These lobes differ significantly in shape and width; while the $\mathrm{E}_{1}$ lobe is $\mathrm{V}$-shaped and rather wide, the $\mathrm{E}_{3}$ and $\mathrm{E}_{4}$ lobes show a tendency to become lanceolate and very narrow. The incipient $\mathrm{E}_{5}$ lobe is shallow and rounded. Specimen MB.C.22033.1 (appr. $100 \mathrm{~mm}$ in dm) shows a similar suture line, but at this size, five secondary prongs of the external lobe are present (Fig. 16A). 


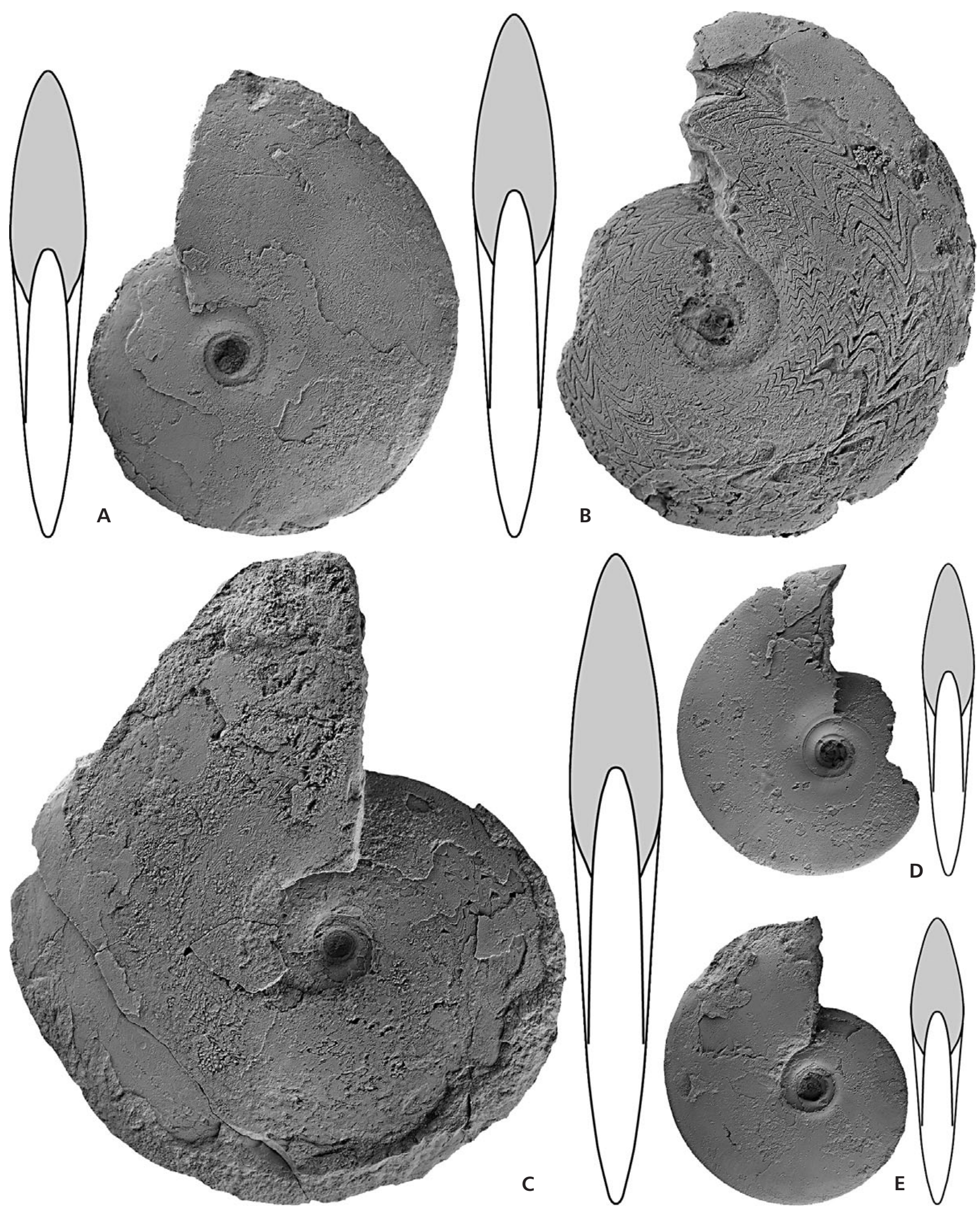

Figure 15. Beloceras petterae Yatskov, 1990 from the Anti-Atlas of Morocco; all × 1.0. • A - specimen MB.C.22032 (Bockwinkel Coll.) from Ouidane Chebbi. • B - specimen MB.C.22039 (Wendt Coll.) from El Khraouia. •C - specimen MB.C.22034 (Bockwinkel Coll.) from Ouidane Chebbi. • D - specimen MB.C.22040.1 (Wendt Coll.) from Lahmida. • E - specimen MB.C.22040.2 (Wendt Coll.) from Lahmida. 

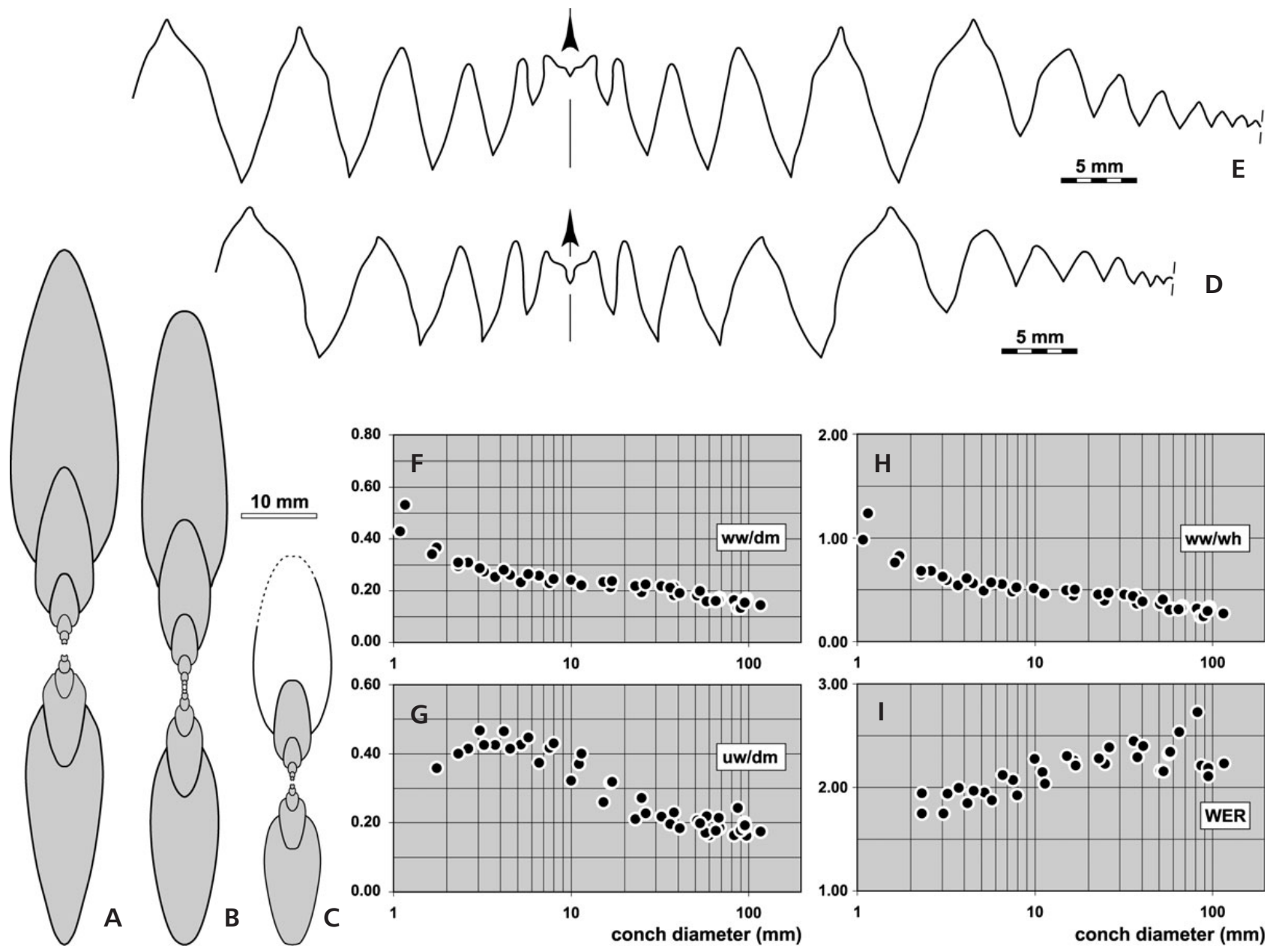

Figure 16. Beloceras petterae Yatskov, 1990 from the Anti-Atlas of Morocco. • A - cross section of specimen MB.C.22033.1 (Bockwinkel Coll.) from El Atrous; $\times 1.0$. $\bullet$ B - cross section of specimen MB.C.22035 (Bockwinkel Coll.) from Ouidane Chebbi; $\times 1.0$. $\bullet$ C - cross section of specimen MB.C.22046 (Ebbighausen Coll.) from El Haroun; $\times$ 1.0. • D - suture line of specimen MB.C.22032 (Bockwinkel Coll.) from Ouidane Chebbi, at 80.7 $\mathrm{mm} \mathrm{dm}, 12.8 \mathrm{~mm}$ ww, $39.6 \mathrm{~mm}$ wh; $\times 2.0$. $\bullet$ E - suture line of specimen MB.C.22033.1 (Bockwinkel Coll.) from Hassi Nebech, at $13.2 \mathrm{~mm}$ ww, ca 50 mm wh; $\times 2.0 . \bullet \mathrm{F}-\mathrm{I}-$ ontogenetic development of the conch width index (ww/dm), umbilical width index (uw/dm), whorl width index (ww/wh), and whorl expansion rate (WER) of all available specimens.

Comparisons. - Beloceras petterae differs from the Beloceras species from Central Europe (B. webbelense, B. tenuistriatum, and B. sagittarium), the Altay (B. bogoslovskyi and B. stenumbilicatum) as well as the Canning Basin (B. glenisteri) in the rather regular zigzag pattern of the secondary prongs of the external lobes and the saddles between them and thus can be easily recognised.

\section{Beloceras jorfense sp. nov.}

Figures 17, 18

Derivation of name. - Named after the Jorf village near Erfoud.

Holotype. - Specimen MB.C.22047 (Wendt Coll.); illustrated here in Fig. 17.
Type locality and horizon. - Tantana near Jorf (eastern Anti-Atlas); greenish-grey Frasnian limestones.

Material. - The holotype and paratype MB.C.22048.

Diagnosis. - Species of Beloceras with subinvolute conch (uw/dm $=0.16$ in stages larger than $50 \mathrm{~mm}$ in $\mathrm{dm}$ ). Suture line with five secondary prongs of the external lobe, a $\mathrm{V}$-shaped lateral lobe, and four umbilical lobes on the flanks at $60 \mathrm{~mm}$ conch diameter; formula of the ventral suture line in this growth stage $\left(E_{2} E_{3} E_{4} E_{5} E_{6} E_{1} E_{6} E_{5} E_{4} E_{3} E_{2}\right) L U_{2}$ $\left.\mathrm{U}_{4} \mathrm{U}_{6} \mathrm{U}_{8} \mathrm{U}_{10}\right)$. Prongs of the external lobe are narrowly $\mathrm{V}$-shaped to lanceolate; L lobe lanceolate; the saddles between the $\mathrm{L}$ lobe and the $\mathrm{E}_{3}$ lobe are weakly tectiform.

Description. - Holotype MB.C.22047 (Wendt Coll.; Fig. 17) is a moderately well preserved, nearly fully septate 


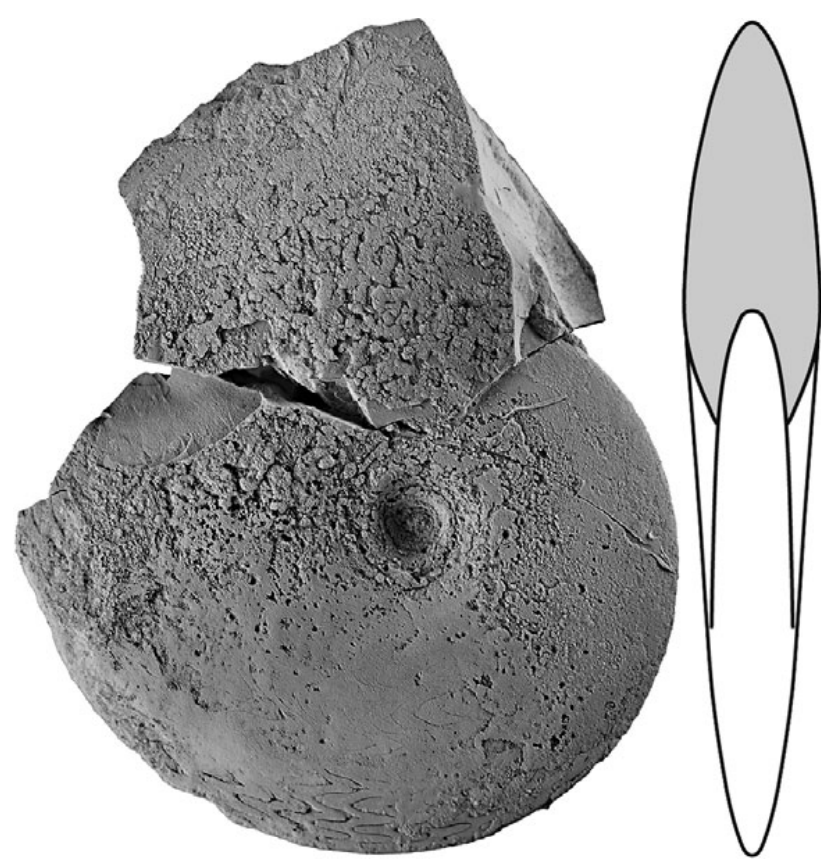

Figure 17. Beloceras jorfense sp. nov. from the Anti-Atlas of Morocco, holotype MB.C.22047 (Wendt Coll.) from Tantana; × 1.0.

specimen with $85 \mathrm{~mm}$ conch diameter. It is extremely discoidal and subinvolute $(\mathrm{ww} / \mathrm{dm}=0.16 ; \mathrm{uw} / \mathrm{dm}=0.16)$ with a very high aperture (WER $=2.42$ ). It has a slightly concave umbilical wall and a very narrow venter. The su- ture line, drawn at $61 \mathrm{~mm}$ conch diameter, shows five secondary prongs of the external lobe (Fig. 18B). These lobes differ markedly in their shape; the $\mathrm{E}_{2}$ prong is lanceolate with diverging flanks, the $\mathrm{E}_{3}$ prong is narrowly $\mathrm{V}$-shaped with slightly sinuous flanks, the $\mathrm{E}_{4}$ prong is lanceolate and asymmetric, the $\mathrm{E}_{5}$ prong is lanceolate and slightly pouched, and the $\mathrm{E}_{6}$ prong is narrowly $\mathrm{V}$-shaped and acute. The saddles between the $\mathrm{E}$ lobe prongs also differ in their shape; while the $E_{2} / E_{3}$ saddle is tectiform, the $E_{3} / E_{4}$ saddle is triangular and narrowly rounded and the two following saddles are tongue-shaped and have a well-rounded top. The L lobe is lanceolate with almost parallel flanks, and the $\mathrm{U}$ lobes are small and V-shaped.

The smaller paratype MB.C.22048 is a fragment with a conch diameter measuring $50 \mathrm{~mm}$. It is strongly corroded from one side, but the other side displays the suture line (Fig. 18A). At a whorl height of $19 \mathrm{~mm}$ (corresponding to about $40 \mathrm{~mm}$ in $\mathrm{dm}$ ), there are four fully developed secondary prongs of the external lobe. As in the holotype, their shapes differ from each other. The saddles between the $\mathrm{L}$ lobe and the $\mathrm{E}_{3}$ lobe are tectiform with a narrow lappet on the top.

Comparisons. - The new species differs from the other North African species B. petterae in the more advanced suture line with lanceolate lobes. B. tenuistriatum is similar but possesses more sutural elements (seven secondary prongs of the external lobe, six or more umbilical lobes on the flank).
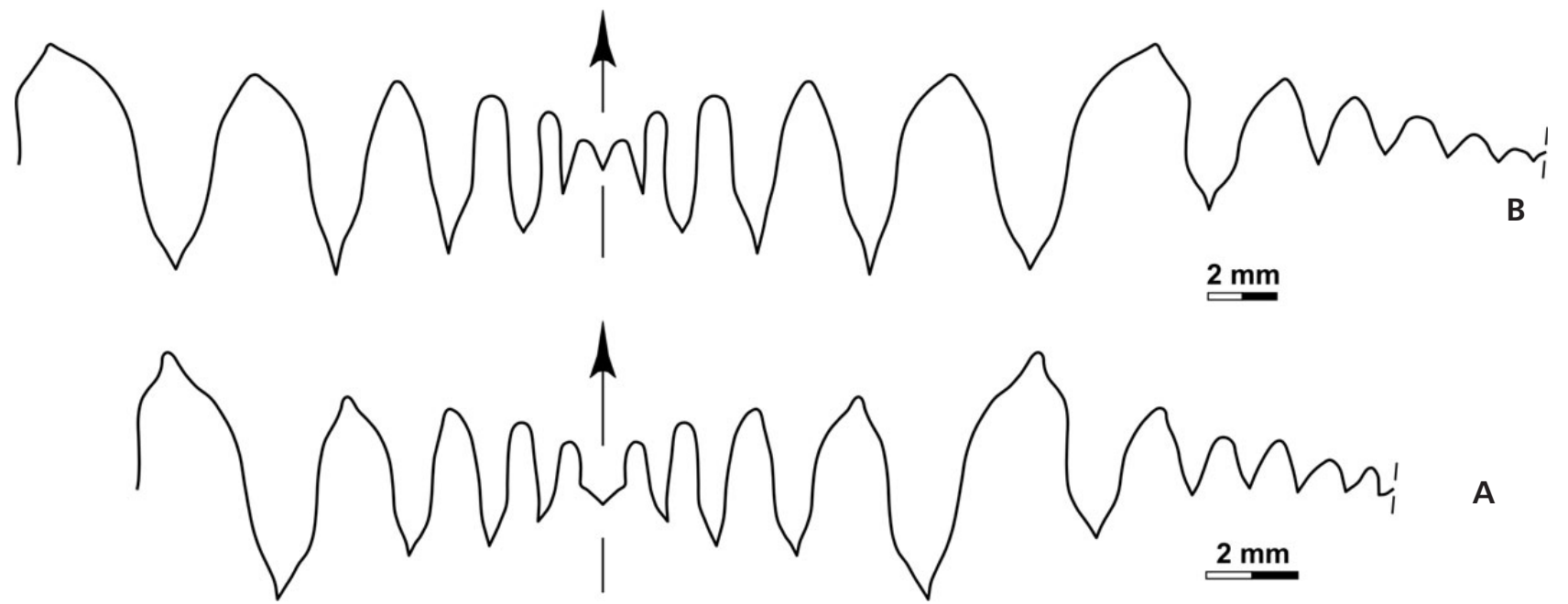

A

Figure 18. Beloceras jorfense sp. nov. from the Anti-Atlas of Morocco. • A - suture line of paratype MB.C.22048 (Wendt Coll.) from Tantana, at ca. $19 \mathrm{~mm}$ wh; $\times$ 4.0. • B - suture line of holotype MB.C.22047 (Wendt Coll.) from Tantana, at $61.1 \mathrm{~mm} \mathrm{dm}, 10.7 \mathrm{~mm}$ ww, $30.0 \mathrm{~mm}$ wh; $\times 3.0$.

Table 11. Conch dimensions (in $\mathrm{mm}$ ) and proportions for the holotype of Beloceras jorfense sp. nov.

\begin{tabular}{cccccccccccc}
\hline & $\mathrm{dm}$ & ww & wh & uw & ah & ww/dm & ww/wh & uw/dm & WER & IZR \\
\hline MB.C.22047 & 84.9 & 13.8 & 40.4 & 13.4 & 30.3 & 0.16 & 0.34 & 0.16 & 2.42 & 0.25 \\
\hline
\end{tabular}




\section{Acknowledgements}

We are indebted to Konrad Bartzsch (Saalfeld), Jobst Wendt (Tübingen), and Dieter Weyer (Berlin) for the donation of their collections. Evelin Stenzel (Berlin) is acknowledged for the preparation of the specimens, and we thank Katharina Dreger and Lina Gebhardt (Berlin) for photographing the specimens. The manuscript profited from the reviews by Kenneth de Baets (Zurich) and Jerzy Dzik (Warsaw).

\section{References}

Archiac, V. D' \& Verneuil, M.E. DE 1842. On the Fossils of the Older Deposits in the Rhenish Provinces; preceded by a general Survey of the Fauna of the Palaeozoic Rocks, and followed by a Tabular List of the Organic Remains of the Devonian. Transactions of the Geological Society of London (2)6, 303-410. DOI 10.1144/transgslb.6.2.303

Becker, R.T. \& House, M.R. 1994. Kellwasser Events and goniatite successions in the Devonian of the Montagne Noire with comments on possible causations. Courier Forschungsinstitut Senckenberg 169, 45-77.

BeCKER, R.T. \& House, M.R. 2000. Devonian ammonoid zones and their correlation with established series and stage boundaries. Courier Forschungsinstitut Senckenberg 220, 113-151.

Becker, R.T., House, M.R., Menner, V.V. \& Ovnatanova, N.S. 2000. Revision of ammonoid biostratigraphy in the Frasnian (Upper Devonian) of the Southern Timan (Northeast Russian Platform). Acta Geologica Polonica 50, 67-97.

Belka, Z., Klug, C., Kaufmann, B., Korn, D., Döring, S., Feist, R. \& WENDT, J. 1999. Devonian conodont and ammonoid succession of the eastern Tafilalt (Ouidane Chebbi section), Anti-Atlas, Morocco. Acta Geologica Polonica 49(1), 1-23.

BEYRICH, E. 1837a. Beiträge zur Kenntniss der Versteinerungen des Rheinischen Übergangsgebirges. 44 pp. F. Dümmler, Berlin.

BEYRICH, E. 1837b. De goniatitis in montibus Rhenanis occurentibus. 18 pp. Typis Academiae regiae scientiarum, Berrolini.

BogoslovsKy, B.I. 1955. O semeystve Pharciceratidae Hyatt, 1900. Doklady Akademii Nauk SSSR 103(6), 1103-1106.

BogoslovsKy, B.I. 1957. K voprosu o klassifikatsi agoniatitov. Doklady Akademii Nauk SSSR 116(3), 489-493.

Bogoslovsky, B.I. 1958. Devonskie ammonoidei Rudnogo Altaya. Trudy Paleontologicheskogo Instituta Akademiya Nauk SSSR 64, 1-155.

BogoslovsKy, B.I. 1969. Devonskie ammonoidei. I. Agoniatity. Trudy Paleontologicheskogo Instituta Akademiya Nauk SSSR 124, 1-341.

BöHM, R. 1935. Études sur les faunes du Dévonien superieur et de Carbonifère inférieur de la Montagne Noire. 203 pp. Unpublished Ph.D. dissertation, Université de Montpellier, Montpellier.

BronN, H.G. 1832. Die Versteinerungen des Salza-Thales, in Beziehung auf Lill von Lilienbach's Beschreibung dortiger Gebirgs-Formationen. Jahrbuch für Mineralogie, Geognosie, Geologie und Petrefaktenkunde 3, 150-182.
Chao King-Koo 1956. Notes on some Devonian ammonoids from Southern Kwangsi. Acta Palaeontologica Sinica 4(2), 101-116.

Clarke, J.M. 1899. The Naples fauna (fauna with Manticoceras intumescens) in Western New York. Annual Report of the New York State Museum 5, 31-161.

Clausen, C.-D. 1969. Oberdevonische Cephalopoden aus dem Rheinischen Schiefergebirge. II. Gephuroceratidae, Beloceratidae. Palaeontographica, Abteilung A 132, 95-178.

Clausen, C.-D., Korn, D. \& Luppold, F.W. 1991. Litho- und Biofazies des mittel- bis oberdevonischen Karbonatprofiles am Beringhäuser Tunnel (Messinghäuser Sattel, nördliches Rheinisches Schiefergebirge). Geologie und Paläontologie in Westfalen 18, 7-65.

Foord, A.H. \& CRICK, G.C. 1897. Catalogue of the fossil Cephalopoda in the British Museum (Natural History), Part III, Containing the Bactritidae and part of the suborder Ammonoidea. 303 pp. Dulau \& Co., London.

FRECH, F. 1897-1902. Lethaea geognostica oder Beschreibung und Abbildung der für die Gebirgs-Formationen bezeichnendsten Versteinerungen. I. Theil. Lethaea palaeozoica. 2. Band. IV, 257-452. Schweizerbart, Stuttgart.

FreCH, F. 1902. Über devonische Ammoneen. Beiträge zur Paläontologie Österreich-Ungarns und des Orients 14, 27-112.

GLENISTER, B.F. 1958. Upper Devonian ammonoids from the Manticoceras Zone, Fitzroy Basin, Western Australia. Journal of Paleontology 32, 50-96.

Hermite, H. 1887. Études géologiques sur les îles Baléares: Première partie: Majorique et Minorique. 362 pp. Savy, Paris.

HolzAPFel, E. 1882. Die Goniatitenkalke von Adorf in Waldeck. Palaeontographica, Neue Folge 8, 225-261.

Holzapfel, E. 1899. Die Cephalopoden des Domanik im südlichen Timan. Trudy Geologicheskogo Komiteta 12(3), $1-56$.

House, M.R. 1963. Devonian ammonoid successions and facies in Devon and Cornwall. Quarterly Journal of the Geological Society of London 119, 1-27.

DOI 10.1144/gsigs.119.1.0001

House, M.R. 1971. The goniatite wrinkle-layer. Smithsonian Contributions to Paleontology 3, 23-32.

House, M.R. \& ZiEGLER, W. 1977. The goniatite and conodont sequences in the early Upper Devonian at Adorf, Germany. Geologica at Palaeontologica 11, 69-108.

House, M.R., Kirchgasser, W.T., Price, J.D. \& Wade, G. 1985. Goniatites from Frasnian (Upper Devonian) and adjacent strata of the Montagne Noire. Hercynica 1, 1-19.

Hyatt, A. 1883-1884. Genera of fossil cephalopods. Proceedings of the Boston Society of Natural History, 253-338.

Konn, D. 2010. A key for the description of Palaeozoic ammonoids. Fossil Record 13(1), 5-12. DOI 10.1002/mmng.200900008

Korn, D. \& Klug, C. 2002. Ammoneae Devonicae. Fossilium Catalogus. I. Animalia 138. 375 pp. Backhuys Publishers, Leiden.

KoRn, D. \& KLug, C. 2007. Conch Form Analysis, Variability, Morphological Disparity, and Mode of Life of the Frasnian (Late Devonian) Ammonoid Manticoceras from Coumiac (Montagne Noire, France), 57-85. In Landman, N.H., Davis, R.A. \& MAPes, R.H. (eds) Cephalopods Present and Past: 
New Insights and Fresh Perspectives. Springer, New York. DOI 10.1007/978-1-4020-6806-5_3

Kullmann, J. 1960. Die Ammonoidea des Devon im Kantabrischen Gebirge (Nordspanien). Abhandlungen der Akademie der Wissenschaften und der Literatur, Mainz, mathematisch-naturwissenschaftliche Klasse 1960(7), 1-105.

Kullmann, J. 1963. Las series devónicas y del Carbonífero inferior con ammonoideos de la Cordillera Cantábrica. Estudios Geológicos 19, 161-191.

Matern, H. 1931. Das Oberdevon der Dill-Mulde. Abhandlungen der Preußischen Geologischen Landesanstalt, Neue Folge 134, 1-139.

Miller, A.K., Furnish, W.M. \& Schindewolf, O.H. 1957. Paleozoic Ammonoidea, L11-L79. In Moore, R.C. (ed.) Treatise on Invertebrate Paleontology, Part L, Mollusca 4, Cephalopoda, Ammonoidea. Lawrence, Kansas.

MülLER, K.J. 1956. Cephalopodenfauna und Stratigraphie des Oberdevons von Schleiz und Zeulenroda in Thüringen. Beihefte zum Geologischen Jahrbuch 2, 1-93.

Petter, G. 1959. Goniatites dévoniennes du Sahara. Publications du Service de la Carte Géologique de l'Algérie, Mémoire Paléontologie 2, 1-313.

RUAN YI-PING 1981. Devonian and earliest Carboniferous Ammonoids from Guangxi and Guizhou. Memoirs of the Nanjing Institute of Geology and Palaeontology, Academia Sinica 15, $1-152$.

RuZHENCEV, V.E. 1957. Filogeneticheskaya sistema paleozoiskikh ammonoidei. Byulleten' Moskovskogo Obshchestva Ispytateley Prirody, Otdel Geologicheskiy 32(2), 49-64.

SANDBERgER, G. \& SANDBERGER, F. 1850-1856. Die Versteinerungen des rheinischen Schichtensystems in Nassau. Mit einer kurzgefassten Geognosie dieses Gebietes und mit steter Berücksichtigung analoger Schichten anderer Länder. I-XIV, 564 pp., 41 pl. Kreidel \& Niedner, Wiesbaden.

SAnz-López, J. 2002. Devonian and Carboniferous preStephanian rocks from the Pyrenees. In GARCíA-LÓPEZ, S. \& BAstidA, F. (eds) Palaeozoic conodonts from northern Spain: Eigth International Conodont Symposium held in Europe. Instituto Geológico y Minero de Espańa, Serie Cuadernos del Museo Geominero 1(2002), 367-389.

Schindewolf, O.H. 1929. Vergleichende Studien zur Phylogenie, Morphologie und Terminologie der Ammoneen-Lobenlinie. Abhandlungen der Preußischen Geologischen Landesanstalt, Neue Folge 115, 1-102.

SchindewOLF, O.H. 1936. Neue Gattungen tiefoberdevonischer Goniatiten. Zeitschrift der Deutschen Geologischen Gesellschaft 88, 689-691.

SCHINDEWOLF, O.H. 1940. „Konvergenzen“ bei Korallen und
Ammoneen. Fortschritte der Geologie und Paläontologie 1241, 389-492.

Schindewolf, O.H. 1955. Zur Taxonomie und Nomenklatur der Clymenien. Ein Epilog. Neues Jahrbuch für Mineralogie, Geologie und Paläontologie, Monatshefte 1955, 417-429.

Schulz, H.D. 1967. Beloceras mit ceratischen Loben aus der Montagne Noire, Frankreich. Neues Jahrbuch für Geologie und Paläontologie, Monatshefte 1967(10), 608-619.

SeILACHER, A. 1975. Mechanische Simulation und funktionelle Evolution des Ammoniten-Septums. Paläontologische Zeitschrift 49(3), 268-286.

TeICHERT, C. 1941. Upper Devonian Goniatite Succession of Western Australia. American Journal of Science 239, 148-153. DOI 10.2475/ajs.239.2.148

Teichert, C. 1943. The Devonian of Western Australia. A Preliminary Review. Parts I and II. American Journal of Science 241, 69-94. DOI 10.2475/ajs.241.2.69

Termier, G. \& Termier, H. 1950. Paléontologie Marocaine. II. Invertébrés de l'ére Primaire. Fascicule III. Mollusques. Notes et mémoires, Service Géologique, Protectorat de la République Française au Maroc, Direction de la Production Industrielle et des Mines, Division des Mines et de la Géologie 78, 1-246.

WEDEKIND, R. 1913. Die Goniatitenkalke des unteren Oberdevon von Martenberg bei Adorf. Sitzungsberichte der Gesellschaft Naturforschender Freunde zu Berlin 1913, 23-77.

Wederind, R. 1918. Die Genera der Palaeoammonoidea (Goniatiten). Mit Ausschluß der Mimoceratidae, Glyphioceratidae und Prolecanitidae. Palaeontographica 62, 85-184.

Wendt, J., Kaufmann, B., Belka, Z., Farsan, N. \& Karimi BAVANDPUR, A. 2005. Devonian/Lower Carboniferous stratigraphy, facies patterns and palaeogeography of Iran Part II. Northern and central Iran. Acta Geologica Polonica 55(1), 31-97.

Weyer, D., Feist, R. \& Girard, C. 2003. Conodonta, Trilobita, and Anthozoa near the Late Frasnian Upper Kellwasser Event of the Geipel Quarry section in Schleiz, Thuringian Mountains (Germany). Mitteilungen aus dem Museum für Naturkunde in Berlin, Geowissenschaftliche Reihe 6(2003), 71-78. DOI 10.1002/mmng.20030060104

YANG JIKAI 1984. Devonian System and its ammonoid fauna from Baoshan district, West Yunnan. Journal of the Chengdu College of Geology 1984, 22-36.

YAтsKov, S.V. 1990. K sistematike semeystva Beloceratidae (Ammonoidea). Trudy Paleontologicheskogo Instituta Akademii Nauk SSSR 243, 36-51.

YAZDI, M. 1999. Late Devonian-Carboniferous conodonts from eastern Iran. Rivista Italiana di Paleontologia e Stratigrafia 105, 167-200. 


\section{Appendix}

Investigated material of Beloceras (catalogue number in the Museum für Naturkunde, Berlin; locality details according to labels connected with the specimens; collector and year; size and preservation of the specimens; lithology of the rock material).

Beloceras sagittarium (Sandberger \& Sandberger, 1851)

\begin{tabular}{|c|c|c|c|c|}
\hline MB.C.4501 & Sessacker bei Oberscheld & Dannenberg & $115 \mathrm{~mm}$ & red-violet limestone \\
\hline MB.C.4502 & Oberscheld, Staatliche Grube & Hubach & $51 \mathrm{~mm}$ & violet hematite ore \\
\hline MB.C.4504 & Charlottenzug bei Bredelar & Denckmann & $70 \mathrm{~mm}$, fragment & red iron limestone \\
\hline MB.C.19171 & Halde der Grube Charlottenzug bei Bredelar & Denckmann 1893 & $86 \mathrm{~mm}$ & red iron limestone \\
\hline MB.C. 19172 & Halde der Grube Charlottenzug bei Bredelar & Denckmann 1893 & $62 \mathrm{~mm}$ & red iron limestone \\
\hline MB.C.19173 & Grube Charlottenzug bei Bredelar & Müller 1883 & $69 \mathrm{~mm}$ & red iron limestone \\
\hline MB.C.19174 & Grube Charlottenzug bei Bredelar & Müller 1882 & $37 \mathrm{~mm}$ & red iron limestone \\
\hline MB.C.19175 & Bredelar & & $67 \mathrm{~mm}$ & red-violet limestone \\
\hline MB.C.19176 & Sessacker b. Oberscheld & Lotz 1901 & $100 \mathrm{~mm}$ & red-violet limestone \\
\hline MB.C.19177 & Sessacker bei Oberscheld & Lotz 1901 & $77 \mathrm{~mm}$ & red-violet limestone \\
\hline MB.C.19178 & Arpe, östlich P. 547,6 & Mempel & $42 \mathrm{~mm}$ & $\begin{array}{l}\text { light grey dolomitic } \\
\text { limestone }\end{array}$ \\
\hline MB.C.19179 & Beuel bei Borg & Denckmann 1900 & $47 \mathrm{~mm}$ & grey limestone \\
\hline MB.C.19180 & Beuel bei Balve, Adorfer Kalk & Denckmann 1902 & $117 \mathrm{~mm}$ & light brown limestone \\
\hline MB.C.19181 & Schmidt's Kalkofen bei Braunau & Denckmann 1888 & $99 \mathrm{~mm}$ & light brown limestone \\
\hline MB.C.19182 & Schmidt's Steinbruch am Kalkofen bei Braunau & Denckmann 1888 & $105 \mathrm{~mm}$ & light grey limestone \\
\hline MB.C.19183 & Braunsberg bei Tegau, toI delta & E. Schultz 1967 & $135 \mathrm{~mm}$ & dark grey limestone \\
\hline MB.C.19184 & Braunsberg bei Tegau, toI delta & E. Schultz 1967 & $59 \mathrm{~mm}$ & dark grey limestone \\
\hline MB.C.19185 & Braunsberg bei Tegau, toI delta & E. Schultz 1967 & $34 \mathrm{~mm}$ & dark grey limestone \\
\hline MB.C.19186 & Braunsberg bei Tegau, toI delta & E. Schultz 1967 & $78 \mathrm{~mm}$ & dark grey limestone \\
\hline MB.C.19187 & Braunsberg bei Tegau, toI delta & E. Schultz 1967 & $40 \mathrm{~mm}$ & dark grey limestone \\
\hline MB.C.19188 & Braunsberg bei Tegau, toI delta & E. Schultz 1967 & $46 \mathrm{~mm}$ & dark grey limestone \\
\hline MB.C.19189 & Braunsberg bei Tegau, toI delta & E. Schultz 1967 & $86 \mathrm{~mm}$ & dark grey limestone \\
\hline MB.C.19190 & Braunsberg bei Tegau, toI delta & E. Schultz 1967 & $122 \mathrm{~mm}$ & dark grey limestone \\
\hline MB.C.19191 & Braunsberg bei Tegau, toI delta & E. Schultz 1967 & $49 \mathrm{~mm}$ & dark grey limestone \\
\hline MB.C.19192 & Braunsberg bei Tegau, toI delta & E. Schultz 1967 & $90 \mathrm{~mm}$ & dark grey limestone \\
\hline MB.C.19193.1-9 & Braunsberg bei Tegau, toI delta & E. Schultz 1967 & nine fragments & dark grey limestone \\
\hline MB.C.19194 & Vogelsberg bei Göschitz & Bartzsch \& Weyer 1985 & $106 \mathrm{~mm}$ & red-violet limestone \\
\hline MB.C.19195 & Vogelsberg bei Göschitz & Bartzsch \& Weyer 1985 & $91 \mathrm{~mm}$ & red-violet limestone \\
\hline MB.C.19196 & Vogelsberg bei Göschitz & Bartzsch \& Weyer 1985 & $106 \mathrm{~mm}$ & red-violet limestone \\
\hline MB.C.19197 & Vogelsberg bei Göschitz, sample VO3 & Bartzsch \& Weyer 1985 & $105 \mathrm{~mm}$, incomplete & red-violet limestone \\
\hline MB.C.19198 & Vogelsberg bei Göschitz, sample VO3 & Bartzsch \& Weyer 1985 & $90 \mathrm{~mm}$ & red-violet limestone \\
\hline MB.C.19199 & Vogelsberg bei Göschitz, 31-41 cm über UKWK & KBartzsch \& Weyer 1985 & $129 \mathrm{~mm}$, incomplete & red-violet limestone \\
\hline MB.C.19200 & Vogelsberg bei Göschitz, sample B & Bartzsch \& Weyer 1985 & $115 \mathrm{~mm}$, incomplete & red-violet limestone \\
\hline MB.C.21998 & Vogelsberg bei Göschitz, bed 19 & Bartzsch \& Weyer 1985 & fragment & red-violet limestone \\
\hline MB.C.21999.1-2 & Vogelsberg bei Göschitz, bed 21, 22 & Bartzsch \& Weyer 1985 & two fragments & red-violet limestone \\
\hline MB.C.22000.1-2 & Schleiz, Geipel quarry, bet 4B & Bartzsch \& Weyer 1995 & $\begin{array}{l}\text { two fragments, poorly } \\
\text { preserved }\end{array}$ & grey limestone \\
\hline MB.C.22001.1-4 & Schleiz, Geipel quarry, bet 4A & Bartzsch \& Weyer 1995 & $\begin{array}{l}\text { four fragments, poorly } \\
\text { preserved }\end{array}$ & grey limestone \\
\hline MB.C.22002 & $\begin{array}{l}\text { Büdesheim, Baugrube Lagerhalle } 700 \text { m ESE } \\
\text { Kirche }\end{array}$ & Ebbighausen 2001 & large fragment & $\begin{array}{l}\text { nearly white dolomitic } \\
\text { limestone }\end{array}$ \\
\hline MB.C.22003.1 & Büdesheim, Bahnhofstraße, Schicht B & Bockwinkel 1996 & $25 \mathrm{~mm}$ & pyritized \\
\hline
\end{tabular}


Dieter Korn et al. • Beloceras, the most multilobate Late Devonian ammonoids

$\begin{array}{ll}\text { MB.C.22003.2 } & \text { Büdesheim, Bahnhofstraße, Schicht B } \\ \text { MB.C.22003.3 } & \text { Büdesheim, Bahnhofstraße, Schicht B } \\ \text { MB.C.22003.4 } & \text { Büdesheim, Bahnhofstraße, Schicht B } \\ \text { MB.C.22004.1 } & \text { Büdesheim, Bahnhofstraße, Schicht C } \\ \text { MB.C.22004.2 } & \text { Büdesheim, Bahnhofstraße, Schicht D } \\ \text { MB.C.22004.3 } & \text { Büdesheim, Bahnhofstraße, Schicht B1 } \\ \text { MB.C.22004.4 } & \text { Büdesheim, Bahnhofstraße, Schicht D } \\ \text { MB.C.22004.5 } & \text { Büdesheim, Bahnhofstraße, Schicht B1 } \\ \text { MB.C.22005 } & \text { Büdesheim }\end{array}$

Beloceras tenuistriatum (d'Archiac \& de Verneuil, 1842)

\begin{tabular}{|c|c|}
\hline MB.C.4505 & Martenberg bei Bredelar \\
\hline MB.C.4506 & Martenberg bei Bredelar \\
\hline MB.C.4507.1 & Martenberg \\
\hline MB.C.4507.2 & Martenberg \\
\hline MB.C.4507.3 & Martenberg \\
\hline MB.C. 4507.4 & Martenberg \\
\hline MB.C.4507.5 & Martenberg \\
\hline MB.C.4507.6 & Martenberg \\
\hline MB.C.7701 & zw. Adorf und Giershagen \\
\hline MB.C.22007 & Grube Martenberg bei Adorf \\
\hline MB.C.22006 & Bredelar \\
\hline MB.C.22008 & Martenberg \\
\hline MB.C. 22010 & Martenberg-Klippe \\
\hline MB.C.22011 & Martenberger Tagebau \\
\hline MB.C.22012.1 & Martenberg bei Adorf \\
\hline MB.C.22012.2 & Martenberg bei Adorf \\
\hline MB.C. 22012.3 & Martenberg bei Adorf \\
\hline MB.C.22012.1-4 & Martenberg bei Adorf \\
\hline MB.C.22014 & Oberscheld, Königszug Mine \\
\hline MB.C.22015 & Oberscheld \\
\hline MB.C.22016 & Oberscheld \\
\hline MB.C. 22017 & Grube Stillingseisenzug, bei dem Lager auf $60 \mathrm{~m}$ \\
\hline MB.C. 22018 & Grube Stillingseisenzug, bei dem Lager auf $60 \mathrm{~m}$ \\
\hline MB.C.22019 & Tagebau Diana bei Oberscheld \\
\hline MB.C. 22020 & Tagebau Diana bei Oberscheld \\
\hline MB.C. 22021 & Tagebau Diana bei Oberscheld \\
\hline MB.C. 22022 & Tagebau Diana bei Oberscheld \\
\hline MB.C. 22023 & Tagebau Diana bei Oberscheld \\
\hline MB.C.22024 & Tagebau Diana bei Oberscheld \\
\hline
\end{tabular}

$\begin{array}{ll}\text { Bockwinkel } 1996 & 10 \mathrm{~mm} \\ \text { Bockwinkel } 1996 & 7 \mathrm{~mm} \\ \text { Bockwinkel } 1996 & 14 \mathrm{~mm} \\ \text { Ebbighausen } 1996 & 9 \mathrm{~mm} \\ \text { Ebbighausen } 1996 & 11 \mathrm{~mm} \\ \text { Ebbighausen } 1996 & 11 \mathrm{~mm} \\ \text { Ebbighausen } 1996 & 8 \mathrm{~mm} \\ \text { Ebbighausen } 1996 & 7 \mathrm{~mm} \\ \text { Zich } & 25 \mathrm{~mm}\end{array}$

pyritized

pyritized

pyritized

pyritized

pyritized

pyritized

pyritized

pyritized

pyritized

\begin{tabular}{|c|c|c|}
\hline Müller & $48 \mathrm{~mm}$ & red iron limestone \\
\hline Müller & $71 \mathrm{~mm}$ & red limestone \\
\hline Müller & $16 \mathrm{~mm}$ & red-violet limestone \\
\hline Müller & $18 \mathrm{~mm}$ & red-violet limestone \\
\hline Müller & $31 \mathrm{~mm}$ & red-violet limestone \\
\hline Müller & $20 \mathrm{~mm}$ & red-violet limestone \\
\hline Müller & $17 \mathrm{~mm}$ & red-violet limestone \\
\hline Müller & $21 \mathrm{~mm}$ & red-violet limestone \\
\hline von Koenen & $64 \mathrm{~mm}$ & red limestone \\
\hline Denckmann 1893 & $51 \mathrm{~mm}$ & red limestone \\
\hline Reinke 1882 & $75 \mathrm{~mm}$ & red iron limestone \\
\hline Denckmann 1893 & $70 \mathrm{~mm}$ & reddish grey limestone \\
\hline Paeckelmann 1928 & $54 \mathrm{~mm}$ & red limestone \\
\hline Denckmann & $73 \mathrm{~mm}$ & red limestone \\
\hline Hugo Kemna & $42 \mathrm{~mm}$ & red-violet limestone \\
\hline Hugo Kemna & $30 \mathrm{~mm}$ & red-violet limestone \\
\hline \multirow[t]{2}{*}{ Hugo Kemna } & $24 \mathrm{~mm}$ & red-violet limestone \\
\hline & four fragments & red limestone \\
\hline Lotz 1901-1902 & $80 \mathrm{~mm}$ & red-violet ironstone \\
\hline Euel 1901 & $52 \mathrm{~mm}$ & red-violet ironstone \\
\hline Dannenberg & fragment & red-violet ironstone \\
\hline Euel 1902 & fragment & red-violet ironstone \\
\hline Euel 1902 & fragment & red-violet ironstone \\
\hline Lotz 1901 & $71 \mathrm{~mm}$ & brown limestone \\
\hline Lotz 1901 & $40 \mathrm{~mm}$ & brown limestone \\
\hline Lotz 1901 & $49 \mathrm{~mm}$ & brown limestone \\
\hline Lotz 1901 & fragment & brown limestone \\
\hline Lotz 1901 & fragment & brown limestone \\
\hline Lotz 1901 & fragment & brown limestone \\
\hline
\end{tabular}


Beloceras webbelense sp. nov.

\begin{tabular}{|c|c|c|c|c|}
\hline MB.C.22025 & Martenberg (Klippe) b. Adorf, Webeler Kalk & Paeckelmann 1920 & $91 \mathrm{~mm}$ & red limestone \\
\hline MB.C.22026 & Martenberg (Klippe) b. Adorf, Webeler Kalk & Paeckelmann 1920 & $52 \mathrm{~mm}$ & red ironstone \\
\hline MB.C. $22027.1-7$ & Gr. Webbel bei Giershagen & & seven fragments & red limestone \\
\hline MB.C. $22028.1-4$ & Webbel bei Adorf & Denckmann & four fragments & red limestone \\
\hline MB.C.22029 & Versuchsschacht 200 m ö. Tagebau Webbel, Webbeler Kalk & Paeckelmann 1920 & $36 \mathrm{~mm}$ & red limestone \\
\hline MB.C.22030 & Webbel bei Adorf & Denckmann & $27 \mathrm{~mm}$ & red limestone \\
\hline MB.C.22009 & Martenberg-Klippe & Paeckelmann 1928 & $76 \mathrm{~mm}$ & red limestone \\
\hline
\end{tabular}

Beloceras petterae Yatskov, 1990

\begin{tabular}{|c|c|c|c|c|}
\hline MB.C.22032 & Ouidane Chebbi & Bockwinkel & $81 \mathrm{~mm}$ & light-grey limestone \\
\hline MB.C.22033.1-7 & Hassi Nebech N $30^{\circ} 56.028$, W $3^{\circ} 48.170$ & $\begin{array}{l}\text { Bockwinkel } \\
\text { 03.03.2010 }\end{array}$ & seven fragments & light-grey limestone \\
\hline MB.C.22034 & Ouidane Chebbi & Bockwinkel & $114 \mathrm{~mm}$ & light-grey limestone \\
\hline MB.C.22035 & Ouidane Chebbi & Bockwinkel & $85 \mathrm{~mm}$ & light-grey limestone \\
\hline MB.C.22036 & Ouidane Chebbi & Bockwinkel & $83 \mathrm{~mm}$ & light-grey limestone \\
\hline MB.C.22037.1-12 & Rich Haroun Kasbah N $31^{\circ} 18.981$ N, W $4^{\circ} 11.380$ & Bockwinkel & twelve fragments & light-grey limestone \\
\hline MB.C.22039 & El Khraouia & Wendt & $93 \mathrm{~mm}$ & red-stained grey limestone \\
\hline MB.C.22040.1 & Rheris, Barrage et Canal Lahmida & Wendt & $56 \mathrm{~mm}$ & light-grey limestone \\
\hline MB.C. 22040.2 & Rheris, Barrage et Canal Lahmida & Wendt & $52 \mathrm{~mm}$ & light-grey limestone \\
\hline MB.C. 22038 & El Atrous, blaue Lage & Bockwinkel & $94 \mathrm{~mm}$ & dark-grey limestone \\
\hline MB.C.22041.1-2 & Rich Haroun & Weyer & two incomplete specimens & light-grey limestone \\
\hline MB.C. 22042 & Ouidane Chebbi & Korn 1993 & $107 \mathrm{~mm}$, incomplete & light-grey limestone \\
\hline MB.C. 22043 & Bou N'Chebbi & Ebbighausen 2000 & fragment & light-grey limestone \\
\hline MB.C.22044.1-2 & Mkarig & Ebbighausen 2001 & two fragments & light-grey limestone \\
\hline MB.C. $22045.1-4$ & Hassi Nebech N $30^{\circ} 56.240$, W $3^{\circ} 47.058$ & Ebbighausen & four incomplete specimens & light-grey limestone \\
\hline MB.C. 22046 & Rich Haroun & Ebbighausen 2010 & $50 \mathrm{~mm}$ & light-grey limestone \\
\hline
\end{tabular}

Beloceras jorfense sp. nov.

$\begin{array}{lllll}\text { MB.C.22047 } & \text { Tantana } & \text { Wendt } & 85 \mathrm{~mm} & \text { light-grey limestone } \\ \text { MB.C.22048 } & \text { Tantana } & \text { Wendt } & 61 \mathrm{~mm} & \text { light-grey limestone }\end{array}$

Beloceras sp. indet.

\begin{tabular}{|c|c|c|c|c|}
\hline MB.C.22049 & Sessacker bei Oberscheld & Dannenberg & fragment & red-violet limestone \\
\hline MB.C.22052 & südwestlich Ober-Valbert & Henke 1913 & fragment & light-grey limestone \\
\hline MB.C.22053 & Weg von Langenholthausen nach Garbeck & Denckmann 1900 & fragment & dark-grey limestone \\
\hline MB.C.22054 & Kalkbruch b. Dorlar & Henke 1909 & fragment & light-grey limestone \\
\hline MB.C.22055 & Deutmecke & Henke 1911 & fragment & light-grey limestone \\
\hline MB.C.22056 & Eisborn, Weg nach Mailinde & Denckmann 1902 & $94 \mathrm{~mm}$ & light-grey limestone \\
\hline MB.C.22057 & Beuel, Recke (Horster) Stbr. & Denckmann 1902 & fragment & red limestone \\
\hline MB.C. $22058.1-3$ & Martenberg bei Adorf & & three fragments & red limestone \\
\hline MB.C.22059 & Grube Martenberg bei Adorf & Denckmann & fragment & red limestone \\
\hline MB.C. 22050 & Sessacker bei Oberscheld & Dannenberg & fragment & red limestone \\
\hline MB.C.22051 & Sessacker bei Oberscheld & Dannenberg & fragment & red limestone \\
\hline MB.C. 22060 & Hauern, Schmidt's Kalkofen & Denckmann 1892 & $110 \mathrm{~mm}$ & light-grey limestone \\
\hline MB.C.22061 & M'Doura west side & Wendt & strongly weathered & light-grey limestone \\
\hline MB.C. 22062 & Rich el Haroun & Wendt & strongly weathered & light-grey limestone \\
\hline
\end{tabular}

